\title{
Examining Sex Offender Community Notification Laws
}

\author{
Abril R. Bedarf $\uparrow$
}

In recent years, sex offender registration laws have attracted widespread attention and support. Thirty-eight states have enacted such statutes, and the remaining states must adopt sex offender registration laws to avoid cutbacks in federal funding. These statutes require convicted sex offenders to register with police when moving into a community or changing their address. Most states limit access to sex offender registration data to the police, who lack the time and resources to verify and update the tremendous volume of information that sex offender registration generates. The result is an unwieldy database with little practical utility. In response, several states recently have adopted community notification laws that allow public access to sex offender registration data. These statutes seek to empower the community by enabling concerned citizens to monitor the activities of convicted sex offenders living in their community. This Comment suggests that community notification laws do not provide a reliable mechanism for tracking sex offenders as they move, and thus are no more effective than police registration. Moreover, community notification programs incite panic and violence within the community, and thereby prevent reformed sex offenders from reintegrating into the community. The author concludes that community notification laws are constitutionally infirm because they offend the dignity of man, and thus violate the Eighth Amendment guarantee against cruel and unusual punishment.

\section{INTRODUCTION}

In response to public concern about sex offenders, many states have enacted sex offender registration laws in recent years. These laws require convicted sex offenders to register with the police in their place of residence and to notify police of any change of address for a set period of years. Legislators justify these laws by citing high rates of recidivism among sex offenders and thus a need to keep the offenders under police surveillance.

Copyright (C) 1995 California Law Review, Inc.

$\dagger$ A.B. 1991, Princeton University; J.D. candidate 1995, Boalt Hall Scloool of Law, University of California, Berkcley. Thanks to the 1994-95 Notes and Comments editors for their persistent encouragement; to David King, Chris Pederson, JoAn Clio, and Mitch Zuklie for their thoughtful editing; and to George Turner for his constant faith in me. 
While most of these laws mandate that sex offender registry information be available only to law enforcement personnel, recent statutes indicate a growing trend among states to allow public access to such information. This Comment takes a closer look at sex offender registration laws and their recent progeny, community notification laws. ${ }^{1}$ This examination reveals that community notification laws are an meffective response to the problems which plague registration laws. This Comment concludes that community notification laws raise political, and, more importantly, constitutional problems that argue agamst their wisdom and validity.

Part I of this Comment provides an overview of current sex offender registration laws. Part II examines the rationale behind the registration laws - sex offender recidivism - and concludes that recidivism statistics have been mamipulated to gam support for registration. Part III analyzes the effectiveness of registration statutes in terms of their purported goals and concludes that these registration schemes are largely imeffcctive. Part IV introduces an emerging response to this ineffectiveness: community notification laws. While community notification laws respond to frustrations with registration programs, this Comment suggests that community notification retains many of the same problems, and introduces significant new ones.

Part $V$ offers a policy critique of community notification laws based on an examination of their effects on the offender and their ability to protect the cominunity. Part VI reviews legal challenges to sex offender registration and community notification laws and advocates an Eighth Amendment analysis of community notification laws. The Cominent concludes that most cominunity notification proposals not only harm the sex offender and the community, but also threaten constitutional values. Although one model of community notification promises to restrain these dangers, it still cannot remedy the problems inherent to sex offender registration schemes.

$I$

Overview of Sex Offender Registration Statutes

At least thirty-eight states currently have some type of sex offender registration statute on their books, ${ }^{2}$ and several other states are considering

1. This Comment uses the term "community notification" to refer to any law which allows public access to or publication of sex offender registration information. For more detail on the provisions of specific community notification laws, see Part IV.

2. ALA. CODE $\S \S 13 \mathrm{~A}-11-200$ to -203 (1994); ALASKa Stat. $\$ \S 12.63 .010,-.020,-.100$ (Supp. 1994); Aruz. Rev. Stat. AnN. §§ 13-3821 to -3824 (1989 \& Supp. 1994); ARK. Code ANn. §§ 12-12901 to -909 (Michie Supp. 1993); Cat. Penal Code $§ 290$ (West Supp. 1994); Colo. Rev. Stat. AnN. $\S 18-3-412.5$ (West Supp. 1994); Det. Code AnN. tit. 11, $\S 4120$ (Supp. 1994); Fla. Stat. ANN. $\S \S 775.21-23$ (West Supp. 1994); IDAHO CODE $\S \S 18-8301$ to -8311 (Supp. 1994); ILL. ANN. STAT. ch. 730, paras. 150/1-150/10 (Smith-Hurd 1992 \& Supp. 1994); IND. CoDE ANN. §§ 5-2-12-1 to -13 (West 1994); Kan. Stat. AnN. $\$ \S 22-4901$ to -4910 (Supp. 1993); Ky. Rev. Stat. ANN. $\$ \S 17.500-.540$ (Michie/Bobbs-Merrill Supp. 1994); LA. Rev. Stat. ANN. $\$ \S 15: 540$ to :549 (West Supp. 1994); Act of May 9, 1995, 1995 Md. Laws 142; ME. REv. Stat. ANN. tit. 34-A, $\S \S 1100$ I-1 1004 (West Supp. 1994); 
enacting similar statutes. ${ }^{3}$ Most of these laws have been passed within the past few years, indicating a recent surge in popularity for this method of dealing with convicted sex offenders. ${ }^{4}$ With the passage of the Violent Crime Control and Law Enforcement Act in September 1994, all states must soon enact some form of registration law within three years, or suffer cutbacks in federal funding for crime control programs. ${ }^{5}$

In general, the current laws follow a similar pattern, with variations in specific provisions such as the specific offenses that trigger registration requireinents, the penalties for failure to register, and the type of information contained in the registry. The degree to which the statutes allow public access to the registry also varies from state to state. Parts IV to VI will examine public access in greater detail. This Part will outline the basic structure of current sex offender registration laws.

MinN. Stat. ANN. § 243.166 (West 1992 \& Supp. 1994); Miss. Code ANN. §§ 45-33-1 to -15 (Supp. 1994); Mo. AnN. Stat. \$§ 566.600-.625 (Vemon 1995); Mont. Code ANN. \$§ 46-23-501 to -507 (1991); Nev. Rev. Stat. AnN. §§ 207.151-.157 (Michie 1992 \& Supp. 1993); N.H. Rev. Stat. ANN. $\S \S 632-A: 11$ to -A:19 (Supp. 1993); Act of Oct. 31, 1994, 1994 N.J. Sess. Law Serv. 128, 133 (West); Act of Apr. 5, 1995, 1995 N.M. Laws 827; N.D. Cent. Code $\$ 12.1-32-15$ (Supp. 1993); Oho Rev. CODE ANN. $\$ \S 2950.01-.99$ (Anderson 1993); OKLA. STAT. ANN. tit. 57, $\$$ 581-587 (West 1991 \& Supp. 1995); OR. Rev. StaT. \$§ 181.517-.519 (Supp. 1994); R.I. GEN. Laws § 11-37-16 (Supp. 1993); S.D. Codrfed LAws ANN. $\S \S 22-22-31$ to -39 (Supp. 1994); TenN. Code ANN. $\S \S 40-39-101$ to -108 (Supp. 1994); Tex. Rev. CIv. Stat. AnN. art. 6252-13c.1 (West Supp. 1994); Utaf Code ANN. § $77-$ 27-21.5 (Supp. 1994); VA. Code ANN. \$§ 19,2-298.1 to -298.3 (Michie Supp. 1994); Wash. Rev. Code ANN. §§ 9A.44.130-,140 (West Supp. 1994); W. VA. CodE §§ 61-8F-1 to -8 (Supp. 1994); Wis. Stat. ANN. § 175.45 (West Supp. 1994); Wyo. StaT. §§ 7-19-301 to -306 (Supp. 1994).

Because of the growing popularity of these laws, additional states may have passed registration laws by the time this Comment is published. This list is current as of May, 1995.

3. See, e.g., Karen Levine, Sex Offenders Should Alert Police, Mass. LAw. WKLy., Aug. 30, 1993, at 24; see also H.B. 2316, Haw. Leg., 17th Leg., 1994 Sess.; S.B. 18, Md. Leg., 408th Leg., 1994 Sess.; H.B. 1123, Miss. Leg., 162d Leg., 1994 Sess.; S.B. 6552, N.Y. Leg., 215th Gen. Assem., 2d Sess.; S.B. 170, N.C. Leg., 1994 Extra Sess.; S.B. 1545, Pa. Leg., 178th Gen. Assem., 1993-94 Sess.

As mentioned in the previous note, it is impossible to provide lere a completely accurate picture of the status of registration laws because the laws are clianging so rapidly. It is likely that several other states will have considered enacting registration laws by the time this Comment reaclies publication.

In addition, Canada las considered enacting a national registry for convicted sex offenders. See Tracey Tyler, Law Forces Sex Offenders Out in Open, Toronto Star, Mar. 27, 1993, at A1.

4. In 1947, California was the first state to enact a sex offender registration statute. Arizona followed in 1951, Nevada in 1961, and Alabama in 1967. Illinois adopted its registration law in 1986, and Arkansas passed its version in 1987. Since 1989, sex offender registration laws have proliferated: for example, Oklahoma in 1989, Washington in 1990, Colorado and Maine in 1991, Louisiana, Minnesota, and Rhode Island in 1992, 1daho and West Virginia in 1993, and New Jersey and Delaware in 1994.

5. Pub. L. No. 103-322, § 170101(f)(2)(A), 1994 U.S.C.C.A.N. (108 Stat.) 1796, 2038-42. The registration provisions required by the Act are similar to many state provisions already in place. Compare id. $\$ 170101$ (a), (b), (c) with infra notes 17-33 and accompanying text.

The sex offender registration provisions of the Act are included under Title XVII-Crimes Against Children, Subtitle A-Jacob Wetterling Crimes Against Children and Sexually Violent Offender Registration Act. The registration act is named after a boy who was abducted in 1989 . Neither the kidnapper nor Jacob have been found. The boy's mother, Patty Wetterling, started the Jacob Wetterling Foundation to lobby for registration laws. Daniel R. Browning, Measure Would Establish National Registry of Sex Offenders, Sr. Louns Post-Dispatch, Dec. 19, 1993, at 7A. 


\section{A. Who Is Required to Register?}

Almost all of the registration statutes enumerate the offenses that require registration. ${ }^{6}$ For the most part, the statutes focus on sexual assaults, including forcible rape and sodomy, and sexual abuse of children, mcluding imcest. ${ }^{7}$ Several statutes also target promoters of child pornography and child prostitution. ${ }^{8}$ Lesser crimes such as indecent exposure or public indecency are enumerated in some of the statutes. ${ }^{9}$ A few states require registration for relatively benign offenses: adultery in Arizona, ${ }^{10}$ bigamy im Louisiana, ${ }^{11}$ and voyeurism in Ohio. ${ }^{12}$

A number of states have focused their registration statutes exclusively on offenders against children, ${ }^{13}$ while some have focused on habitual sex offenders. ${ }^{14}$ Generally, the statutes also cover convictions obtained in other jurisdictions for crimes substantially similar to the state's own registrable sex offenses. ${ }^{15}$ In addition, many of the statutes imclude attempts to commit any of the listed offenses. ${ }^{16}$

6. Alabama is unusual in that it lists several specific crimes which fall under the statute's jurisdiction, but does not limit the statute's application to those offenses listed. Instead, it applies the statute generally to any act of sexual abuse or sexual perversion with a member of the same or opposite SeX. ALA. CODE § 13A-11-200.

7. See, e.g., Ala. CodE $\S 13 A-11-200$ (including id. $\S 13 A-13-3$ (incest)); Nev. Rev. Stat. ANN. $\S 207.151$ (2) (including id. $\$ 201.180$ (incest)).

8. See, e.g., ARIz. Rev. Stat. ANN. $\S 13-3821$ (A) (including id. $\S 13-3552$ (commercial sexual exploitation of children)); Tex. Rev. Civ. Stat. ANN. $\S 6252-13$ C.1, sec. 1, 5(B) (including id. $\S 43.25$ (coercing sexual performance by a child)).

9. See, e.g., CAL. PENAL CodE $§ 290($ a) (including id. § 314(1), (2) (indecent exposure)); Ono REv. CODE ANN. $\$ 2950.01$ (B)(I) (including id. $\$ 2907.09$ (public indecency)).

10. Artz. Rev. Stat. ANN. § I3-3821(A) (including id. § 13-1408 (adultery)).

11. LA. Rev. Stat. ANN. \$15:542(E) (including id. § 14:76 (bigamy)).

12. OHIO Rev. CODE ANN. $\$ 2950.01(B)(1)$ (including id. $\$ 2907.08$ (voycurism)).

13. See, e.g., ARK. CODE ANN. \$ 12-12-901 (Habitual Child Sex Offender Registration Act); Colo. Rev. Stat. ANN. § 18-3-412.5 (duty to register for sex offenses against children); ILl. ANN. STAT. ch. 730, para. 150/1 (Child Sex Offender Registration Aet); IND. CODE ANN. \$ 5-2-12-4 (defining sex offender as one convicted of specified sex offenses against children); ME. REv. STAT. ANN. tit. 34A, $\S 11002$ (2) (defining sex offender for purposes of statute as an individual convicted of gross sexual assault upon victim under sixtcen).

14. See, e.g., ARK. CODE ANN. § 12-12-901 (Habitual Child Sex Offender Registration Act); OHo REV. CODE ANN. \$2950.02 (requiring any "habitual sex offender," defined as any person convicted two or more times of an enumerated sex offense, id. $\$ 2950.01(\mathrm{~A})$, to register with police). Minnesota rcquires rcgistration of "predatory" criminals who are sentenced as patterned offenders. MINN. STAT. $\S 243.166$, subd. 1(2).

15. See, e.g., OR. REv. STAT. $\$ 181.519$ (1)(a) ("or when a person convicted in another jurisdiction of a crime that would constitute a sex crime if committed in this state . ..."); W. VA. CoDE $\$ 61-8 F-2$ ("Any person who has been convicted of a violation of the provisions described in . . . this chapter or similar provisions in another jurisdiction . ...").

16. See, e.g., Nev. Rev. Stat. ANN. \$ 207.151(3) (crimes include "an attempt to commit any offense listed in [the previous subsections]"); OKLA. STAT. ANN. tit. 57, § 582 (statute applics to persons who attempt to commit covered crimes). 


\section{B. Timetables: When to Register and for How Long?}

Upon commencement of probation or release from prison, convicted sex offenders generally must register with the chief of police im the area in which they imtend to live. ${ }^{17}$ In most jurisdictions, the sex offender has thirty days to complete the registration requirement before a penalty accrues. ${ }^{18}$ Registration is required even if the offender intends to reside only temporarily at that location. ${ }^{19}$ When a registered sex offender moves, $\mathrm{he}^{20}$ must notify the authorities of his new address within a specified time frame. ${ }^{21}$

17. Typically, the statute requires a sex offender to register with the chief of police when residing in a city or municipality, and to register with the sheriff of the county when living in an unincorporated area. See, e.g., Ark. Code Ann. § 12-12-904(a); Cal. Penal Code § 290(a); Oho Rev. Code. AnN. $\S 2950.02$. West Virginia requires offenders to register with the county division of public safety. W. VA. CODE $§ 61-8 \mathrm{~F}-2$.

18. Some states have shorter time frames, allowing the offender less than thirty days to initiate registration. See, eg., Cal. Penal Code § 290(a) (fourteen days); Colo. Rev. Stat. Ann. § 18-3412.5(3) (seven days); IDAHo Code § 18-8304(1) (five days); ME. Rev. Stat. AnN. tit. 34-A, $\S 11003$ (1) (fifteen days); Nev. Rev. STat. ANN. § 207.152(1) (forty-eight hours); OkLA. STAT. ANN. tit. 57, \& 583(A)-(B) (ten days, but allowing thirty days for new residents who were convicted of comparable sex offenses out-of-state); WASH. REv. CODE ANN. §9A.44.130(3)(a)(i) (twenty-four hours).

Penalties for failing to register vary widely. Most statutes classify a violation as a misdemeanor. See, e.g., ARk. Code ANn. § 12-12-903; Car. Penal Code § 290(g)(1); Ill. ANN. Stat. ch. 730, para. 150/10; Minn. Stat. ANN. § 243.166, subd. 5; Nev. Rev. Stat. ANn. § 207.157; OKLA. Stat. ANN. tit. 57, § 587; R.I. GEN. LAWS § 11-37-16(g); UTAH CODE ANN. § 77-27-21.5(10)(a); W. VA. CODE § 61$8 \mathrm{~F}-8$. Some states charge a first violation as a misdemeanor, but increase the classification to felony for a subsequent violation. See, e.g., Colo. Rev. Stat. ANN. § 18-3-412.5(4) (class 2 misdemeanor for first violation, class 6 felony for subsequent violations); OHIO REV. CODE ANN. § 2950.99 (first-degree misdemeanor on first violation, fourth-degree felony on subsequent violations). A few statutes charge a first violation as a felony. See, e.g., ArIz. Rev. Stat. ANN. § 13-3824 (class 6 felony); IDAHo Code $\$ 18-8311$ (felony); 1991 OR. LAws 389.4 (violation of registration is class $C$ felony if underlying crime was felony, otherwise violation is misdemeanor); WASH. REv. CODE ANN. § 9A.44.130(7) (violation is class $C$ felony if the underlying crime was class $A$ felony, otherwise violation is a gross misdemeanor).

Based on these classifications, penalties for violating the registration statutes may include incarceration for misdemeanor or felony terms, a fine, see, e.g., ALA. CODE § 13A-11-203 (violators may be fined up to \$1000); IDAHO CODE § 18-8311 (penalty shall include a fine not to exceed \$5000); OkLA. Stat. Ann. tit. 57, $\$ 587$ (penalty may include fine up to $\$ 1000$ ); W. VA. Code $§ 61-8 \mathrm{~F}-8$ (penalty may include fine from $\$ 50$ to $\$ 500$ ), or an increase in the duration of the registration requirement, see, e.g., MINN. STAT. ANN. $\$ 243.166$, subd. $6(\mathrm{~b})$ (penalty for failure to notify of change of address may consist of additional five-year period of registration).

19. The length of a stay which qualifies as a temporary residence generally coincides with the length of time in which initial registration must be completed.

20. For simplicity's sake, this Comment will use the male pronoun when referring to sex offenders. Certainly, women commit sex offenses as well, but their numbers are far fewer. In 1992, 32,965 men were arrested for forcible rape, as opposed to 420 women. 1992 FBI UNIFORM CRME REPORTS 229-31. Thus, women represented only slightly more than $1 \%$ of the rapists. In that same year, 84,540 men were arrested for sexual offenses other than rape and prostitution, as opposed to 7,020 women. Id. Women represent slightly less than $8 \%$ of the arrests in this category.

21. Usually, the time allowed to register at a new address is less than or equal to the initial registration time allowance. See, e.g., ALA. CODE § 13A-11-200 (thirty days for initial registration and thirty days when moving to another county); ARIz. REv. STAT. ANN. $\$ \S 13-3821$ to -3822 (thirty days for initial registration and thirty days when moving to a new county, but "promptly" when moving within a county); IDAHO CODE § 18-8304(1), (2) (five days for initial registration and five days after any 
Most statutes require registration for a set period of time, ranging from five years to life. ${ }^{22}$ In some states, the duration of the registration requirement is dependent on the severity of the crime. ${ }^{23}$ If the offender does not commit any registrable offenses during the statutory period of registration, the state either automatically terminates the registration obligation or allows the offender to petition for termination of registration upon a showing of rehabilitation..$^{24} \mathrm{~A}$ few statutes impose registration requirements of indeterminate length which the offender may terminate only upon a showing of rehabilitation. ${ }^{25}$

Although an offender's duty to register may expire, the initial registration data usually remams on file indefinitely. While a few states allow the offender to petition for expungement of his records from the registration file, most do not. ${ }^{26}$

\section{Information Required for Registration}

The information required for registration is generally comprehensive. Most states require the offender to provide his name, address, date of birth, social security number, fingerprimts, and photograph, and to specify the offenses he committed and identify the date and place of his convictions. ${ }^{27}$

move); ILL. ANN. STAT. ch. 730, paras. 150/3, $150 / 6$ (thirty days for initial registration, but ten days when moving to new address); ME. REv. STAT. ANN. tit. 34-A, § 11003(1), (3) (fifteen days for initial registration, but only five days when moving); Оно REv. CODE ANN. $§ \S 2950.02,2950.05$ (thirty days initially, ten days when moving). But see NEv. REv. STAT. ANN. $\$ 207.152$ (only forty-eight hours for initial registration, but ten days when moving); WASH. REv. CODE ANN. § 9A.44.130(3)(a)(i) \& (4) (twenty-four hours initially, but ten days when moving).

22. See, e.g., N.H. Rev. Stat. Ann. § 632-A:16(II) (ten years); Oho Rev. Code ANn. § 2950.06 (ten years); UTAH CODE ANN. § 77-27-21.5(8) (five years); W. VA. CODE § 61-8F-4 (ten years); CAL. Penai Code $\$ 290$ (life).

23. See, e.g., Colo. Rev. Stat. ANN. § 18-3-412.5(7)(a)-(c) (twenty years for class 1, 2, or 3 felony, ten years for class 4,5 , or 6 felony, and five years for misdemeanor); WASH. REv. CODE ANN. $\S 9 \mathrm{~A} .44 .140(1)(\mathrm{b})$, (c) (fifteen years for class B felony, ten years for class C felony).

24. See, e.g., ME. REv. STAT. ANN. tit. 34-A, \&11003(1), (4)C-1 (registration terminates automatically after fifteen years, but offender may petition court for termination after five years upon showing of rehabilitation); $1991 \mathrm{O}_{\mathrm{R}}$. LAws 389.5 (offender may petition court after ten years for determination that he is rehabilitated and does not pose a threat to safety of puhlic). Oklahoma has a similar provision which allows offenders who complete the state sex offender treatment program to register for only two years, OKLA. STAT. ANN. tit. $57, \S 583(\mathrm{C})$, inplying that these offenders pose less of a threat after such time than the offenders who do not complete such a program. See id.

25. See, e.g., CAL. PENAI CODE $\S 290.5$ (offender may petition for certifieate of rehabilitation and thus obtain relief from duty to register); NEv. REv. STAT. ANN. $\$ 207.156$ (offender may petition at any time for termination of registration upon showing of rehabilitation); R.I. GEN. LAws $\S 1$ 1-37-16(k) \& \$§ 12-1.3-1 to .3-4 (offender may petition for termination of duty to register); WASH. REv. Code ANN. $\S 9 A .44 .140(1)$ (a), (2), (3) (offenders cenvicted of class A felony can only terminate duty to rcgister by showing that further registration would not serve purposes of statute).

26. See, e.g., IdAHo Code § 18-8310; R.I. Gen. LaWs § 11-37-16(k); VA. Code ANN. § 19.2298.3.

27. See, e.g., Arvz. Rev. Star. AnN. § 13-3821(B) (fingerprints and photo); Ark. Code ANN. $\S 12-12-907$ (date of birth, offenses committed, dates and plaees of convictions, photo, fingerprints, and social security number); IDAHO CODE § 18-8306 (inter alia name and ahases, photo, fingerprints, offenses committed and place where committed, place where incarcerated, current address and place of 
In addition, several states require the offender to disclose any other information requested by the police or other appropriate authority. ${ }^{28}$

\section{Notification to Offender of Registration Requirements}

Not every state makes explicit provisions for notifying a released offender of his duty to register. ${ }^{29}$ Notification provisions, when made, typically require the staff of the prison or other facility in which the offender was confined to notify the offender of his duty to register before his release. If an offender is not mcarcerated, the statute obligates the court to notify the offender at the time of his sentencing. ${ }^{30}$ Although most registration statutes also apply to out-of-state sex offense convictions, only five states make explicit provision for notifying new state residents of the registration requirements. ${ }^{31}$

Most states have no statutory provision for notifying defendants of the registration requirements before they are convicted. Washington is an exception, requiring courts to provide written notification to any defendant charged with a registrable sex offense. ${ }^{32}$ Although California does not impose statutory duties of notification on its courts, the California Supreme Court requires trial courts to notify defendants of their duty to register before accepting defendants' pleas to registrable sex offenses. ${ }^{33}$

employment); Nev. REv. STAT. ANN. $\$ 207.153$ (inter alia "[w] [were he resides, how long he has resided there, how long he expects to reside there, and how long he expects to remain in the county and in the State of Nevada"); OKLA. STAT. ANN. tit. 57, $\S 584(\mathrm{~A})(2)$ (inter alia may include DNA profile if requested by Department of Corrections); OR. REv. STAT. $\$ \S 181.518-.519$ (inter alia description of methodology of the offense).

28. See, e.g., ARIz. Rev. STAT. ANN. § 13-3821(B) (information as required by director of department of public safety); Colo. REv. STAT. ANN. $\$ 18-3-412.5$ (3) (information as required by the local law enforcement agency); ILL. ANN. STAT. ch. 730, para. 150/8 (information as required by Department of State Police); OHo REv. CODE ANN. $\$ 2950.07$ (information as required by burcau of eriminal identification and investigation).

29. Regardless of whether the statute explicitly provides for notice, all states must provide notice to sex offenders of their duty to register. See Lambert v. California, 355 U.S. 225, 229 (1957) (invalidating application of felon registration ordinance to individuals who received no notice of duty to register).

30. See, e.g., ARk. Code AnN. § 12-12-905(b)(1); Cal. Penal Code § 290(b), (c); Ill. AnN. Stat. ch. 730, para. 150/5; Me. Rev. Stat. Ann. tit. 34-A, § 11003(2); Nev. Rev. Stat. AnN. $\S 207.154$.

31. IDAFO CODE $§ 18-8307(3)$ (providing notice with driver's license applications); LA. REv. STAT. ANN. § 15:543(E) (same); N.H. REv. STAT. ANN. § 632-A:13(II) (state department of safety will notify new resident of registration duties if notified of his arrival by out-of-state law enforcement agency); OKLA. STAT. ANN. tit. 57, § 585(B) (providing notice of registration requirements with driver's license applications); WASH. REv. CODE ANN. $\S 46.20 .187$ (same).

32. Wash. Rev. Code ANN. $\S 10.01 .200$ (West Supp. 1994).

33. Bunnell v. Superior Court, 531 P.2d 1086, 1094 (Cal. 1975). Recently, the Cahfornia Supreme Court found that although it was error under Bunnell for a trial court to fail to advise a defendant of his registration obligations under Penal Code $\S 290$ before accepting his plea of guilty to assault with intent to commit rape, such omission did not prejudice defendant nor did it violate the plea agreement under which he was sentenced. People v. McClellan, 862 P.2d 739, 749 (Cal. 1993). Thus, failure to notify a defendant before his guilty plea can be harmless error. 


\section{E. Access to Registry Information}

Until recently, nearly all sex offender registration statutes prohibited access to registry information to all but law enforcement personnel. Those statutes which still restrict access to registry information often set forth detailed procedures for its dissemination to the appropriate law enforcement officials ${ }^{34}$ and exphicitly prohibit the release of this information to others. ${ }^{35}$ These safeguards against release of information are premised on the belief that registration statutes are primarily an aid for law enforcement officials in apprehending suspects for sexual offenses. ${ }^{36}$

Washington state began the moveinent toward public disclosure of sex offender registration information im 1990 when it passed its Community Protection Act, ${ }^{37}$ which allowed police to selectively disseminate information to the public. Louisiana followed in 1992 with an even more radical law requiring sex offenders to identify theinselves to the community directly. ${ }^{38}$ Since then several other states have considered or passed some sort of "community notification" law allowing public access to specific information about sex offenders in their communities. Most recently, New Jersey enacted the so-called "Megan's Law,"39 which has ignited a national debate over the desirability and effectiveness of community notification laws. ${ }^{40}$

To understand the rismg popularity of community notification laws, it is first necessary to examine what purpose registration laws serve, how they have failed, and how community notification laws propose to remedy these failures.

34. E.g., N.D. CENT. CODE $§ 12.1-32-15(3)$ :

The official in charge of the place of confinement ... shall obtain the address where the person expects to reside upon discharge ... and shall give one copy of the form to the [offender] and shall send four copies to the attorney general .... The attorney general shall forward one copy to the law enforcement agency having jurisdiction where the [offender] expects to reside ... one copy to the prosecutor ... and one copy to the court ....

35. See, e.g., UTAH CODE ANN. § 77-27-21.5(11) (Supp. 1994) (such information is "classified as private"); W. VA. CODE § 61-8F-5 (Supp. 1994) (information "shall not be open to inspection by the public, or by any person other than a regularly employed peace or other law-enforcernent offieer"). Some statutes grant immunity to officials who disclose such information to unauthorized persons. NEv. Rev. Stat. ANN. § 207.155(3) (Michie Supp. 1993) (official "who, in good faith, releases or fails to release any registration data pursuant to subsection 2 is immune from any criminal or civil liability ... unless he acted with gross negligence.").

36. See infra notes 86-88 and accompanying text.

37. See, e.g., WASH. Rev. Code ANN. $§ 4.24 .550$ (West Supp. 1994).

38. LA. Rev. Stat. ANN. $\S 15: 574.4(\mathrm{H})(2)$ (West Supp. 1992).

39. See Megan's Law: When a Sex Offender Moves In, Is There a Duty to Warn the Community?, A.B.A. J., Mar. 1995, at 38.

40. See, e.g., Bruce Fein, Yes: Community Self-Defense Laws Are Constitutionally Sound, A.B.A. J., Mar. 1995, at 38; Edward Martone, No: Mere Illusion of Safety Creates Climate of Vigilante Justice, A.B.A. J., Mar. 1995, at 39. 
II

\section{Rationale BEHIND the Registration LAwS}

Legislatures, ${ }^{41}$ courts, ${ }^{42}$ and advocates ${ }^{43}$ all agree that sex offender registration statutes are intended to address the high recidivism rate of sex offenders. ${ }^{44}$ But despite the public perception that recidivism is a more serious problem among sex offenders than other criminals, research on sex offenders in the past few decades reveals that recidivism for sex offenses is relatively low. That the public perception of recidivism rates is false or misleading is reason to question whether registration (and community notification) laws should exist.

\section{A. Studies of Sex Offender Recidivism}

Prior to the 1970s, the majority of criminological studies concluded that dangerous sex offenders had a lower recidivism rate than the average criminal. In 1950, the New Jersey Commission on the Habitual Sex Offender reported that sex offenders had a recidivism rate of only seven percent, based on subsequent arrests for sexual offenses. ${ }^{45}$ This rate was

41. See, e.g., IDAHO CODE $\S 18-8302$ (Supp. 1994) ("The legislature finds that sex offenders present a high risk of reoffense . . . ."); WASH. Rev. CoDE ANN. § 9A.44.130 (West Supp. 1994) (Finding-Policy-Laws) ("The legislature finds that sex offenders often pose a high risk of reoffense ....”.

42. See, e.g., People v. Tate, 210 Cal. Rptr. 117, 119 (Ct. App. 1985) (citing Witkin for the proposition that California's registration requirement is based on the assumption that sex offenders are more likely than other criminals to repeat their crimes); State v. Noble, 829 P.2d 1217, 1224 (Ariz. 1992) (citing research studies on sex offender recidivism to support the assertion that registration statutes serve the important goal of aiding law enforcement in apprehending recidivists).

43. See, e.g., Ken Chavez, Lungren Would Name Child Molesters, Contra Costa Times, Jan. 12, 1994, at 1A, 16A (quoting assemblywoman backing tougher registration law, "It's not a matter of if they are going to commit the act again, they're going to."); It Just Makes Sense, BAY STATE BANNER, Sept. 2, 1993, at 4 (asserting in support of proposed sex offender registration law in Massachusetts that sex offenders are the top recidivists among criminals); Lorraine Woellert, Virginia Bills Propose Registry for Sex Offenders, WASH. Times, Jan. 27, 1994, at Al, A14 (noting that officials justify focus on sex offenders "because they have the highest rate of recidivism.").

44. The American Herrtage Dictionary 1033 (2d College ed. 1982) defines recidivism as a "tendency to return to criminal habits." In this context, the concerm is not just a return to criminal habits, but a return to sexual criminal habits. Thus, unless otherwise noted, all recidivism rates quoted below refer to convicted sex offenders committing subsequent sex offenses after their release from custody.

In studies of criminal recidivism, researchers use either subsequent arrest or conviction data as evidence of recidivism. Obviously, reliance on one or the other may lead to different results, which causes problems when attempting to compare different studies on sex offender recidivism. See Joseph J. Romero \& Linda M. Williams, Recidivism Among Convicted Sex Offenders: A 10-Year Followup Study, 49 Fed. Probation 58, 58 (1985). Some studies use self-reporting of recidivistic bebavior rather than pohice and court records in order to get a more accurate picture of recidivism rates among a particular group. See infra notes 50-53 and accompanying text. Because the studies discussed below do vary im their measures of recidivism, it is important to note which method each study uses in order to compare them fairly.

45. Commission on the Habitual Sex Offender, State of New Jersey, The Habitual Sex OFFENDER 23 (1950) (citing CITY OF NEW YORK, REPORT OF THE MAYOR's COMMITTEE FOR THE STUDY OF SEX OfFenses 93-95 (1940)). The Mayor's Committee found that although one-third of the subject 
lower than all other serious offenses, except murder. ${ }^{46}$ Several researchers in subsequent years agreed with this conclusion, finding that serious sex offenders, such as rapists and child molesters, were not serious recidivists. ${ }^{47}$ In 1965 , one of the most comprehensive studies of recidivism among sex offenders concluded that only $10 \%$ of sex offenders were convicted for another sexual crime within twelve to twenty-four years. ${ }^{48}$

Beginning in the late 1970 s, criminologists reassessed their conclusions about sex offender recidivism, im part because of the wide discrepancy in views between theinselves and psychiatrists who treated sex offenders. ${ }^{49}$ One group of researchers asserted that sex offenders commit an alarming number of sexual offenses for which they are never arrested or convicted. ${ }^{\text {so }}$ Analyzing data collected from confidential questionnaires administered to 137 inen convicted of rape or child molestation, ${ }^{51}$ the researchers found that the men had committed two to five times more undetected sexual crimes than the number for which they were apprehended. ${ }^{52}$ The study concluded that serious sex offenders do have significant rates of recidivism which are not revealed by the conviction data. ${ }^{53}$

In 1985, another group of researchers studied the correlation between recidivism rates and the type of sexual crime committed. ${ }^{54}$ This study

offenders were rearrested within the twelve year period, only one-fifth of those arrests were for sex offenses. Id.

The New Jersey report was influential in shaping professional opinion on sex offender recidivism for the next twenty years. A leading criminological journal printed a condensed version of the report in 1955. See Paul W. Tappan, Some Myths About the Sex Offender, 19 Fed. Probation 7, 8-9 (1955). The same article was reprinted in 1971 in a multi-volume criminal justice treatise. See Paul W. Tappan, Some Myths About the Sex Offender, in I CRIme and Justice: The Criminal in Societr 314 (Leon Radzinowicz \& Marvin E. Wolfgang eds., 1971).

46. Commassion on the Habitual Sex OfFender, supra note 45, at 14.

47. See Karl O. Christiansen et al., Recidivism Among Sexual Offenders, 1 Scandinavian Studies IN CRImnology 55, 59-61 (1965); see also A. Nicholas Groth et al., Undetected Recidivism Among Rapists and Child Molesters, 28 CRME AND DeunQ. 450, 450-51 (1982) (citing several studies which concur with the New Jersey Report).

48. Christiansen et al., supra note 47, at 83. The study observed for a period of 12 to 24 years nearly 3,000 sex offenders who were registered hetween 1929 and 1939. The researchers defined recidivism as receiving a sentence for a subsequent offense. Id. at 59 . Thus, its results are not directly comparable to the New Jersey study and other studies which define recidivism in terms of subsequent arrests.

49. Based on personal contact with serious sex offenders, many psychiatrists of this era believed the sex offender recidivism rate was higher than the criminological studies indicated. See Groth et al, supra note 47, at 451; see also K.L. Soothill \& T.C.N. Gibbeus, Recidivism of Sexual Offenders: $A$ ReAppraisal, 18 BrTt. J. Crmminology 267, 267-68 (1978).

50. Groth et al., supra note 47 , at 456 .

51. Id. at 451-52.

52. Id. at 454 .

53. Id. at 456-57. Because the study compared self-reported sex offenses to convictions for sex offenses, it can only demonstrate the disparity between known recidivism and undetected recidivism. This study did not produce recidivism rates based upon tracking an individual's subsequent sexual offenses after conviction, and thus did not produce statistics directly comparable to other studies.

54. Joseph J. Romero \& Linda M. Williams, Recidivism Among Convicted Sex Offenders: A TenYear Follownp Study, 49 Fed. Probation 58 (1985). 
found that although the average rate of rearrest for a sexual crime among the subjects within the ten year study period was $11.3 \%$, this rate varied significantly with the type of offender: pedophiles at $6.2 \%$, sexual assaulters at $10.4 \%$, and exhibitiomists at $20.5 \% .^{55}$ Furthermore, the data showed that sexual assaulters were nearly as likely to commit nonsexual violent crimes as to commit sexual assaults in their criminal "career," while exhibitiomists and pedophiles demonstrated a greater tendency toward sexual offenses than toward violent nonsexual offenses. ${ }^{56}$ This finding supported a previously asserted contention that sexual assault demonstrates a tendency toward violent behavior which is not always expressed sexually. ${ }^{57}$

As part of an assessment of the effectiveness of the California sex offender registration statute, the California Department of Justice commissioned a study of sex offender recidivism rates in 1988.58 The study analyzed subsequent arrest data for individuals first apprehended in 1973 for a registrable sex offense, and found that $19.7 \%$ of the subjects were rearrested for a registrable sex offense within fifteen years. ${ }^{59}$ The data also showed that subjects who. were first arrested for rape had the highest recidivisin rate for sex offenses among the subject group (25.2\%), while those first arrested for lesser offenses such as mdecent exposure and annoying or molesting behavior demonstrated the lowest recidivism rate for sex offenses $(16.8 \%){ }^{60}$ These results contradicted the 1985 study by Romero and Williams, also based on subsequent arrest data, which found stronger recidivistic tendencies towards sexual offenses among exhibitionists than among rapists. ${ }^{61}$

Finally, a United States Department of Justice report issued in 1989 found that $7.7 \%$ of convicted rapists were rearrested for rape within three years after their release from custody. ${ }^{62}$ In addition, the survey found that "[r]eleased rapists were 10.5 tinies nore likely than nonrapists to have a

55. Id. at 60 .

56. Id. at 62 (finding that sexual assaulters' total "career" arrests consisted of $23.5 \%$ for sexual offenses and $19.4 \%$ for violent nonsexual offenses, while exhibitionists were arrested $41.7 \%$ of the time for sexual offenses and $10.6 \%$ of the time for violent nonsexual offenses, and pedophiles had $31.5 \%$ of their arrests for sexual offenses and $15.6 \%$ of their arrests for other crimes of violence).

57. Id. at 63 .

58. Roy Lewis, Effectiveness of Statutory Requirements for the Registration of Sex Offenders, Report to the California State Legislature 1 (1988).

59. Id. at 7. Note that the initial pool of subjects were arrested for, not convicted of, a sex crime.

60. Id. Subjects first arrested for attempted rape had a recidivism rate of $23.3 \%$ for sex offenses, and individuals first arrested for incest, sodomy, oral copulation, or lewd and lascivious behavior showed a recidivism rate of $17.7 \%$ for sex offenses. Id. The average recidivism rate of $19.7 \%$ results from the greater number of individuals committing offenses such as lewd and lascivious behavior and indecent exposure, who demonstrated lower rates of recidivism than those committing the less frequent crimes of rape and attempted rape.

61. See supra note 55 and accompanying text.

62. Aluen J. Beck \& Bernard E. Shipley, U.S. Dep't of Justice, Recidivism of Prisoners ReLEASED IN 1983, at 6, tbl. 9 (1989). 
subsequent arrest for rape."63 Those who committed sexual assaults other than rape were 7.5 times more likely than other criminals to be rearrested for a nonrape sexual assault. ${ }^{64}$

\section{B. Analysis of Recidivism Data}

Recidivism data for non-sexual offenses place statistics about sexual offenses in perspective. The U.S. Department of Justice study found that rapists have a lower recidivism rate for the same offense than any other class of offender except murderers. While the rearrest rate for rape among previously convicted rapists was $7.7 \%$, the rate for robbery among previously convicted robbers was $19.6 \%$, for assault was $21.9 \%$, for burglary was $31.9 \%$, for larceny was $33.5 \%$, and for drug offenses was $24.8 \%{ }^{65}$ The recidivism rate for murder was $6.6 \%{ }^{66}$ Even with regard to general recidivism, meaming rearrests for any type of offense, sex offenders had low rates: $51.5 \%$ of rapists and $47.9 \%$ of sexual assaulters were rearrested for some crime within three years after release from custody. ${ }^{67}$ By contrast, people arrested for robbery had a general recidivism rate of $66 \%$, for burglary $69.6 \%$, for motor vehicle theft $78.4 \%$, for drug possession $62.8 \%$, and for assault $60.2 \%{ }^{68}$ Those arrested for other offenses had lower rates; for example, the rate for those arrested for murder was $42.1 \%$, for negligent manslaughter $42.5 \%$, and for drug offenses other than possession and trafficking $45.3 \%{ }^{69}$

Although a direct comparison of all the preceding data is impossible given the different data pools and methodology involved in each study, one conclusion nay certainly be drawn: sex offenders are not more likely than other criminals to be recidivists. Even the highest estimate of the percentage of sex offenders who are rearrested for a subsequent sex offense $(25.2 \%)^{70}$ is comparable to, or lower than, the recidivism rates for all other crines, except murder. ${ }^{71}$

63. Id. at $6 \&$ tbl. 10. This statistic has been misquoted in the media. See, e.g., Carolyn Abraham, Perils of Naming Sexual Offenders, OtTawa Citizen, Feb. 20, 1993, at Al (sex offenders are "considered in general 10.5 times more likely than other criminals to reoffend"); Laurie Kellman, Rape Ranks Highest in Crime Repeats, WASH. TIMES, Dec. 12, 1992, at Al ("National statisties show that rapists are 10.5 times more likely than other convicts to repeat their crimes."); see also Don Martinez, Sex Offenders Swamp State, S.F. Exammine, Jan. 16, 1994, at B1, B6 (quoting registration advocate's contention that "sex offenders are more likely to repeat their offense tban any other kind of criminal").

64. Beck \& Shipley, supra note 62 , at $6 \&$ tbl. 10.

65. Id. at 6, tbl. 9 .

66. Id.

67. Id. at 5 , tbl. 8 .

68. Id.

69. Id.

70. See supra note 60 and accompanying text.

71. See supra text accompanying notes 65-66. Note also that the $25.2 \%$ recidivism rate for rapists was obtained over a period of fifteen years, while the comparable figures for other offenders were obtained in only three years. Thus, if fifteen-year tracking statistics were available for non-sex offenders, they undoubtedly would be higher than the figures shown here. 
Of course, sex offenders may commit crimes for which they are never arrested or convicted. ${ }^{72}$ However, this may be true of all criminals. The National Crime Victimization Survey found that victims reported only $30 \%$ of personal thefts, and only $50 \%$ of violent victimizations to the police. ${ }^{73}$ According to the survey, slightly more than half of female rape victims reported the crime to the police. ${ }^{74}$ In total, the survey found that citizens reported to the police only $39 \%$ of the crimes included in the survey. ${ }^{75}$

According to these figures, reporting rates for rape are actually higher than average. This result may be attributed to the severity of the crime and the likelihood of serious physical injury. ${ }^{76}$ The study did not include specific reporting rates for sex offenses other than rape, such as child molestation. However, even if reporting rates for such offenses were significantly lower than for non-sex crimes, it is unlikely that the unreported figures would validate the claim that sex offenders have higher recidivism rates than other criminals. Given that the reported recidivism rate of sex offenders is rather low compared to the rate of other offenders, the underreporting of sex crimes would have to be disproportionately large relative to that of other crimes for the recidivism rate of sex offenders to equal other offenders' recidivism rates.

While it is simply not true that sex offenders have unusually high recidivism rates, they do have a greater tendency to "specialize" in sex offenses. The Department of Justice Statistics reported that rapists were 10.5 times more likely than other types of offenders to be rearrested for rape. ${ }^{77}$ While rapists may have the highest recidivism rates for subsequent rapes, ${ }^{78}$ they are even more likely to be rearrested for robbery, assault, burglary, a drug offense, or a public order offense than they are for rape. ${ }^{79}$ Thus, while most criminals will commit various types of offenses in their criminal careers, only a certain subsection of criminals will commit rape. The best predictor of this subset is those offenders who have already been convicted of rape.

Despite studies indicating low recidivism rates, the public continues to perceive, as it has for decades, that the threat from sex offenders is greater

72. See supra note 50 and accompanying text.

73. Marianne W. Zawitz et aI., U.S. Dep't of Justice, Highights from 20 Years of Surveytng Crime Victoms 31 (1993).

74. Id. at 9.

75. Id. at 31 .

76. See id.

77. See supra note 63 and accompanying text.

78. Contrast rapists' $7.7 \%$ recidivism rate for subsequent rapes with other offenders' recidivism rates for subsequent rapes: murder $0.8 \%$, burglary $0.7 \%$, motor vehicle theft $0.1 \%$, fraud $0.4 \%$, robbery $1.4 \%$, and assault $1.2 \%$. See BECK \& Stripley, supra note 62 , at 6 .

79. The rearrest rate for robbery among previously convicted rapists was $8.5 \%$, for assault $10.7 \%$, for burglary $12.7 \%$, for drug offenses $11.3 \%$, and for public order offenses $22.3 \%$. See id. 
than it actually is. ${ }^{80}$ In 1950 , the New Jersey Commission on the Habitual Sex Offender noted this misperception, indicating that people perceived that violent offenders were prevalent in society, were serious recidivists, and tended to graduate froin minor to serious sexual offenses. ${ }^{81}$ A 1986 Canadian study of public beliefs about crine rcached a similar conclusion. ${ }^{82}$ Although the subjects of the Canadian study overestinated recidivisin rates for all three categories of crines offered (crinnes against property, offenses against the person, and sex offenses), their inisperception was the greatest in the category of sex offenses. While the official rate of sex offender recidivisin was $13.5 \%$, the public estinnate was $57.6 \% .^{83}$ In contrast, the official rate of rccidivisin for property offenses was $27.3 \%$, and the public estinnate was $49.0 \%{ }^{84}$ Thus, while sex offenders had the lowest official rate of recidivisin, the public believed that they had the highest rate.

Advocates of sex offender registration laws continue to fuel this public misperception by touting high recidivisin rates as the reason why registration laws are necessary. ${ }^{85}$ The preceding analysis has shown, however, that recidivisin is not as significant of a problein as these advocates clain. Indeed, if actual recidivism rates inotivated registration laws, drug dealers and burglars should be the prine targets of registration laws, rather than sex offenders.

One response to this criticism inay be that sex offenses cause so inuch harm to the cominunity that registration laws are justified, regardless of the sex offenders' recidivism rate. Such an argument does not consider that legislatures have failed to inpose registration requircments upon other violent offenders, such as robbers and assaulters, who arguably inflict coinparable harm upon the community. Furthermore, this argument ignores the pohitical influence that distorted recidivisin statistics have upon the public and their elected representativcs. These statistics sinultaneously increase the public fear of sex offenders and provide a rationalc for the registration and cominunity notification laws ineant to allay these fcars. Purportedly high sex offender recidivisin rates are thus crucial to the existence and popularity of these laws.

80. The public hysteria over perceived increases in sex offenses and other crimes is examined and criticized in Katherine Dunn, Crime and Embellishment, L.A. Times MaOazine, Apr. 10, 1994, at 24.

81. Commission on the Habitual Sex OfFender, supra note 45, at 13-14.

82. Julian V. Roberts \& Nicholas R. White, Public Estimates of Recidivism Rates: Consequences of a Criminal Stereotype, 28 CANadian J. Criminology 229, 229-31 (1986).

83. Id. at 233.

84. Id.

85. See, e.g., A Unique Category of Criminals, Atzanta Const., Feb. 2, 1994, at A10 (supporting registration law in part because sex offenders are "among the most likcly to repeat their crimes"); Woellert, supra note 43, at A14 ("The registries target sex offenders because they have the highest rate of recidivism ...."). 


\section{III}

\section{EfFectiveness of Registration Laws in Aiding LAW ENFORCEMENT}

In the panic surrounding misperceptions of sex offender recidivism, both legislatures and the public have turned to law enforcement agencies for protection. In fact, the main purpose of registration laws is to provide police with information for use in subsequent investigations of sex offenses. However, due to organizational and financial shortcomings, registration laws have not fulfilled this goal.

\section{A. Goal to Aid Law Enforcement}

Registration laws provide information to the police on the theory that such information will enable the police to protect the public better. This focus on protection moves away from more traditional responses to the sex offender problem, such as sex offender therapy groups, which seek to reliabilitate the sex offender. Indeed, registration laws explicitly reject the idea that the state can rehabilitate sex offenders. ${ }^{86}$

Some registration statutes explicitly identify their goal as assisting law enforcement agencies in protecting the public. ${ }^{87}$ Courts that have examined registration laws have also discerned a goal to assist police in the apprehension of sex offenders. ${ }^{88}$ Therefore, it is against this goal that the effectiveness of sex offender registration laws must be judged.

\section{B. Failure of Registration Laws in Achieving Goal}

Unfortunately, registration statutes have not been effective. Law enforcement agencies have been unable to rely on registration laws in apprehending sex offenders because the agencies lack the enormous resources and personnel necessary to administer the registration laws effectively. These deficiencies in the operation of registration statutes are most evident in Califorma and Washington, where the statutes have come under

86. Supporters of registration laws, in addition to asserting that sex offenders have one of the highest recidivism rates of all criminals, maintain that sex offenders are not susceptible to rehabilitation programs. See, e.g., Unique Category, supra note 85, at A10 (approving of Georgia legisiature's recognition that sex offenders are "among the most difficult criminals to rehabilitate"); UPl, Nov. 6, 1993, available in LEXIS, Nexis Library, UPl file (citing Iowa Attorney General spokesman's statement that child molesters are rarely, if ever, rehabilitated).

87. E.g., IDAHO CODE $§ 18-8302$ (requiring sex offender registration "to assist efforts of local law enforcement agencies" in "protect[ing] their communities . . . and quickly apprehend[ing] offenders who commit sex offenses"); FLA. STAT. ANN. $\$ 775.22(1)$ (stating purpose of law is "to enhance the public safety"); 1991 OR. LAws 389.7 (providing statement of purpose "to assist law enforcement agencies in preventing future sex offenses").

88. E.g., Barrows v. Municipal Court, 464 P.2d 483, 486 (Cal. 1970) (finding purpose of California registration statute was to assure that sex offenders "shall be readily available for police surveillance at all times'); People v. Adams, 581 N.E.2d 637, 640 (Ill. 1991) (finding Illinois Habitual Child Sex Offender Registration Act “designed to aid law enforcement agencies"). 
intense scrutiny by the inedia. ${ }^{89}$ Such operational deficiencies, combined with inherent shortcomings of the registration statutes, demonstrate that registration is an ineffective means of protecting the public from sex offenders.

\section{Ineffective Implementation \\ a. California}

The failure of California's registration program to aid police in apprehending recidivist sex offenders has been evident for at least the past decade. Though the system was enacted in 1947, newspapers have recently lamented the system's inadequacies im light of unsolved or belatedly-solved high-profile sex crime cases. ${ }^{90}$ These stories merely echo sentiment expressed a decade ago when Los Angeles police, during a search for a missing child, found $90 \%$ of Los Angeles-area-registry addresses to be either wrong, out-of-date, or non-existent. ${ }^{91}$

In 1985, the California legislature enacted Senate Bill 888, which required the California Department of Justice to study the effectiveness of the state's sex offender registration requirements. ${ }^{92}$ The Department of Justice study concluded in 1988 that nearly $75 \%$ of registrable sex offenders who were convicted in the few years prior to the study had registered. ${ }^{93}$ However, a closer look at the basis for this conclusion reveals that the actual compliance rate is probably significantly lower.

The study revealed that only $54.3 \%$ of the sex offenders convicted in 1973 were registered in $1988 . .^{94}$ An analysis of the registrable sex offense conviction data froin 1981 demonstrated that $72.2 \%$ of those offenders were on the Sex Registration File. ${ }^{95}$ Thus, the report optimistically concluded,

89. This section focuses on California and Washington because public documentation of the administration of their registration laws is most accessible.

90. See Martinez, supra note 63, at B1 (citing Alameda county and Sacramento cases in which sex offender registry should have assisted in apprehending suspects but did not because of its flaws); Josh Meyer \& Geoffrey Mohan, Flawed System Hampers Valley Molester Search, L.A. Times, Dec. 15, 1993, at Al (police efforts to use registry to identify suspect in San Fernando Valley cases restricted by inadeqnacies of registry); Thaai Walker, 7-Year Old's Slaying a Brutal Indictment of the System, S.F. CHRON., Apr. 4, 1994, at A8 (Pasadena police investigation of girl's disappearance foiled by lack of aecess to neighboring city's sex offender registration data).

91. See Gail D. Cox, County Studies Private Contract to Keep Track of Sex Offenders, L.A. DaIly J., Aug. 25, 1986, $\S \mathrm{II}$, at 1 .

92. Lewis, supra note 58 , at 1.

93. Id. at 2 .

94. Id. at 6.

95. Id. The Sex Registration File is the California Department of Justice Sex Registration Unit's off-line computer file containing registration information for all registered sex offenders in California. Id. at 4. The report does not specify the year in whicl data from the Sex Registration File was used, but since the recidivism study in the subsequent section of the report followed arrest records through 1988, it is likely that the Scx Registration File data was from 1988 as well. 
compliance is improving and "full compliance is not an unreasonable goal." 996

The above data only demonstrate the percentage of offenders who initially complied with the registration requirement. Once a sex offender registers in accordance with Penal Code section 290, his registration information remains in the Sex Registration File for life. However, if the offender moves without notifying the authorities of his new address, his registration information becomes outdated and useless. Because section 290 requires offenders to notify law enforcement authorities of a change of address, offenders who fail to do so violate the registration requirement. The statistics noted above do not distinguish between initial compliance and current compliance, and thus overreport effective compliance with the registration requirement.

In its report, the California Department of Justice recognized the possibility that a significant percentage of the addresses in the Sex Registration File might be out-of-date, but failed to conduct any enipirical investigation into the extent of this problem. Instead, it relied on results from a survey of law enforcement agencies which found contradictory opimons among law enforcement personnel. ${ }^{97}$ On the one hand, a large proportion of participants in the survey believed the system was effective in keeping track of the whereabouts of sex offenders. ${ }^{98}$ On the other hand, when asked to identify problems with the registration system, respondents repeatedly offered "[l]ack of ... up-to-date information" and "[1]ack of knowledge or cooperation on the part of the offender to register and/or provide law enforcement with address changes." $" 99$ Based on these responses and indications fron1 other data, the study concluded that address compliance is "probably quite poor." 100 However, the report failed to emphasize that poor address coinpliance renders the registration program nearly useless.

Law enforcement personnel confirm the inadequacies of the registration progran in practice. They report being overwhelmed by the volume of information, inuch of it outdated, that they receive through sex offender registration. The police have neither the time nor the money to check every name on the registry when attempting to solve a sex crime. Nor is the registry helpful in identifying suspects based on location or type of crime, because the list is often incomplete or inaccurate. ${ }^{101}$ The result is an unwieldy database with little practical utility.

Newspaper reports provide some limited statistical data on the extent of the address compliance problem. In 1984, a San Bernadino County sher-

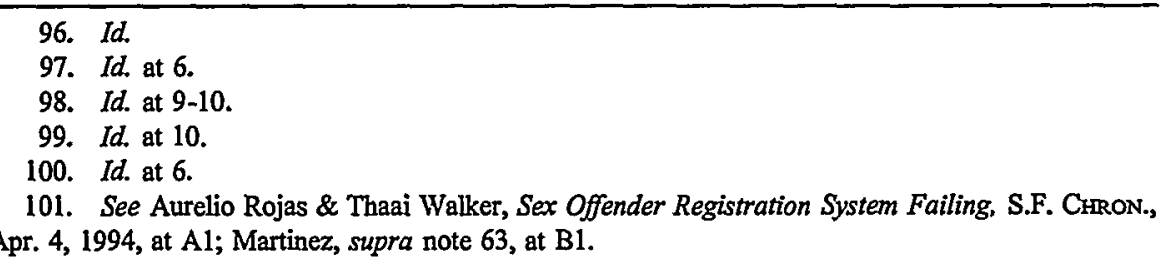


iff's captain attempted to investigate 4400 registered sex offenders in the Los Angeles area in a search for a missing child and found that $90 \%$ of the addresses were inaccurate. ${ }^{102} \mathrm{~A}$ more limited investigation in Sacramento County in December 1993 revealed that approximately 80 out of 100 registered sex offender addresses were incorrect. ${ }^{103}$ Authorities at the California Department of Justice have estimated that the state has accurate information for registered sex offenders approximately $24 \%$ of the time. ${ }^{104}$ Such a low level of accuracy defeats the purpose of the registry, which is to assist law enforcement in apprehending suspects in sexual crimes. ${ }^{105}$

\section{b. Washington}

The story in Washington state is less complete, given that its sex offender registration law was enacted in 1990.106 Reported compliance rates are comparable to those in Califorma, but, as in Califorma, actual compliance is probably much lower. Likewise, Washington state's law enforcement officials report problems in keeping track of offenders as they move, thus calling into question the accuracy of registration data and the effectiveness of the registration program as a whole.

In 1993, state crime analysts estimated the overall initial compliance rate was $80 \% .^{107}$ However, like their counterparts in California, Washington law enforcement officials have a difficult time keeping registry information current and accurate as offenders move. Police generally rely on offenders' voluntary compliance with the change-of-address notification requirement, or on tips from concerned citizens. ${ }^{108}$ Police do not follow up on sex offender registrants because they lack the time, personnel, and inoney to pursue violators of the Act. ${ }^{109}$ Police say their resources are better spent solving actual sex crimes, rather than tracking down offenders who fail to register. ${ }^{110}$

102. See Cox, supra note 91 , §II, at 1.

103. See Meyer \& Mohan, supra note 90 , at A38.

104. See Martinez, supra note 63 , at B1.

105. See supra notes $\mathbf{8 6 - 8 8}$ and accompanying text.

106. This section applies only to the registration provisions of Washington's Community Protection Act. Analysis of the notification provisions of the Washington law will be taken up in Parts V \& VI.

107. See Karen Alexander, Sex Offender Map Stirs Controversy, Seatrle Times, Scpt. 24, 1993, at B1.

108. See Richard Seven, Sex Offender Guilty of Not Registering with Police, SeatTle Times, Jan. 23, 1992, at A1, A3.

109. See Alexander, supra note 107, at B1 (quoting Seattle Police sergeant on follow-up of initial registrants, "We're outgunned and undermanned."); Karen Alexander, Ex-Convict Runs Homes for Sex Offenders, Seatrue Tmmes, Feb. 23, 1994, at B1, B2 (noting that tracking scx offenders is "laborintensive" and that police lack "the manpower to keep up on all of [them]"); Christy Scattarella, Release of Sex-Offender Data Varies by Jurisdiction, Seattle Times, Feb. 20, 1991, at F1 (quoting police spokesman's statement that "[w]e just don't have the manpower to go chasing these people down"); Seven, supra note 108, at A3 (estimating that proper oversight of sex offender list in King County would require five times the personnel currently assigned to it).

110. See Scattarella, supra note 109, at F1. 


\section{The Inherent Deficiency in the Registration Laws}

Evidence from Washington and California demonstrates that registration statutes are not achieving their potential as tracking devices for convicted sex offenders. The primary cause seems to be a lack of resources. In response to this deficiency, some legislatures have demonstrated renewed commitment to funding registration programs. ${ }^{111}$ However, no amount of money can guarantee the accuracy necessary to administer an effective registration program. As one sheriff noted, registration "just keeps honest offenders honest."112 So long as registration depends on the voluntary comphance of convicted sex offenders, it will not reach a comfortable level of accuracy.

Furtherniore, even if registration statutes did produce an accurate database, they still would not protect the public against sex offenders. Because registration is primarily a reactive tool, it comes into play only after a crime has been committed, and may not prevent future crimes. The next Part discusses some controversial responses to these shortcommgs.

\section{IV \\ An EMerging Trend: Community Notification}

Community notification has emerged as a means to transform registration laws into more proactive crime control mechanisms. When registration data is made public, mdividuals may police their own communities to prevent sex crimes, rather than simply react to crimes after they have been committed.

\section{A. Basic Models of Community Notification}

As of January 1995, four states had enacted community notification statutes, and the list of states considering such provisions grows steadily. Eventually, all states will likely enact some version of a community notification law, smce the Violent Crime Control and Law Enforcement Act of 1994 requires each state to adopt limited community notification to remain eligible for certain federal funding. ${ }^{13}$ Four basic models have been enacted or proposed: mandatory self-identification, discretionary police identification, public access to police book, and public access by telephone.

111. See, e.g., S.B. 16, Cal. Leg. 1993-94 1st Extraordinary Sess. (Jan. 27, 1994) (allocating over one million dollars to support the Sex Registration System).

112. See Martinez, supra note 63, at B6.

113. Pub. L. No. 103-322, § 170101, 1994 U.S.C.C.A.N. (108 Stat.) 1796, 2042. The Act provides that each state's registration data shall be confidential, except that "the designated State law enforcement agency ... may release rclevant information that is necessary to protect the public concerning a specific person rcquired to register under this section." Id. § 170101(d)(3). States that do not comply with this provision, and with the other registration requirements of the Act, "shall not receive 10 percent of the funds that would otherwise be allocated to the State under ... the Omnibus Crime Control and Safe Streets Act of 1968." Id. § 170101(f)(2)(A). 


\section{Self-Identification Model}

The self-identification model requires the offender both to identify himself to the community as a sex offender and to register with the police. This model has been in effect in Louisiana since 1992.

Louisiana limits the application of its community notification law to child molesters. ${ }^{14}$ Upon his grant of parole, the offender must notify neighbors and the superintendent of the school district in which he resides of his name, address, and conviction. ${ }^{115}$ In addition to this individualized notification, the offender must publish the same information in the official journal of the municipality in which he lives. ${ }^{116}$ The parole board may also order the offender to declare his status as a sex offender by more novel methods, such as signs, buniper stickers, or labeled clothing. ${ }^{17}$ Since these requirements are provisions of the rules of parole, an offender's duty to comply with them expires with his term of parole. ${ }^{118}$

\section{Police Discretion Model}

In the second model, the police have discretion over whether to relcase infornation to the community about convicted sex offenders. Thus, not all registered sex offenders are revealed to the public. This model has been in effect in Washington state since 1990. The federal Violent Crime Control and Law Enforcement Act of 1994 also follows this model. ${ }^{119}$

The Washington statute allows public agencies to release "relevant and necessary infornnation regarding sex offenders to the public when the release of the information is necessary for public protection."120 The language of the statute offers police little guidance: "Release of information ... will further the governmental interests of public safety and public scrutiny of the criminal and mental health systems so long as the information released is rationally related to the furtherance of those goals." 121 The statute thus gives police wide discretion in deciding whether to release infor-

114. See LA. Rev. Stat. ANn. $\S 15: 574.4(\mathrm{H})(2)$. Anyone who commits a registrable sex offense, id. $\S 15: 542(\mathrm{E})$, against a ehild under the age of 18 is subjeet to eommunity notification upon his parole. Id. § 15:574.4(H)(2).

115. Id. $\S 15: 574.4(\mathrm{H})(2)(\mathrm{a})$.

116. Id. $\$ 15: 574.4(\mathrm{H})(2)(\mathrm{b})$.

117. Id.

118. See id. § 15:574.4(H). Louisiana has also enacted a more moderate community notification provision as part of its registration program, which applies to sex offenses committed against adults as well as children. Id. $\S 15: 546(\mathrm{~A})$; see also id. $\S 15: 542(\mathrm{E})$ (defining sex offense). Because this provision is modeled after the eommunity notification law in Washington state, its basic outline is described in the discussion of the Washington model in the next section of this Comment. Any refcrence to "the Louisiana model" throughout this Comment vill refer to Louisiana's unique "scarlet letter" provision for parolees.

119. Indeed, the legislative history of the Act explicitly referred to the Washington statute as the model for its community notification provisions. 140 CoNG. REC. H5612 (daily ed. July 13, 1994) (statensent of Rep. Dunn).

120. Wash. Rev. CODE $§ 4.24 .550(1)$.

121. Id. $\S 4.24 .550$ (Historieal and Statutory Notes). 
mation, what kind of information to release, and how to disseminate the information. Public officials or employees who release such information are explicitly immune from civil liability for any damages which may result from their decision, unless they acted "with gross negligence or in bad faith." 122

The new federal law uses similar language, authorizing state law enforcement agencies to "release relevant information that is necessary to protect the public concerning a specific person required to register," and granting immunity to officials who disseminate sucl information in good faith. ${ }^{123}$

\section{Police Book Model}

A third model of community notification allows individuals to decide when they want to know about sex offenders in their cominunity. The California legislature recently enacted such a program. It permits individuals to go to their local sheriff's office and peruse a book of registration data and photographs of sex offenders im particular areas.

The infornation consists of a photograph and physical description of the offender, his name, age, zip code, and a list of his registrable sex offenses. ${ }^{124}$ The information is categorized by county and zip code, ${ }^{125}$ allowing individuals to learn the identity of sex offenders in their neighborhood. The specific addresses of offenders are not available to the public under this statute. ${ }^{126}$ Although California requires all sex offenders to register witl the state, this law only allows information about child sex offenders to be released to the public. ${ }^{127}$

\section{Telephone Request Model}

The Califorma law also allows people to find out whether a particular mdividual is a child sex offender by calling a "900" telephone nunber. 128 Callers must provide very specific inforniation, sucli as the exact street address, birth date, or detailed physical description of the person in question, in order to verify registration status. ${ }^{129}$ The statute requires that the

122. Id. $\$ 4.24 .550(2)$. In addition, the statute imposes no liability upon public officials for failing to release such information, but officials may be liable for such failure under other statutes. See id. $\S 4.24 .550(3)$.

123. Pub. L. No. 103-322, § 170101(d)(3), (e), 1994 U.S.C.C.A.N. (108 Stat.) 1796, 2042.

124. Cal. Penal Code $\$ 290.4(b)(1)$.

125. Id. $\S 290.4(\mathrm{~b})(2)$.

126. Id. $\S 290.4(\mathrm{~b})(1)$.

127. See id. $\$ 290.4(a)(1)$.

128. Id. $\S 290.4(\mathrm{a})(3)$. The new section is scheduled to go into effect on July 1,1995 . Id. $\S 290.4(\mathrm{j})$.

129. Id. $\$ 290.4(\mathrm{a})(3)$. 
caller "have a reasonable suspicion that a child is at risk."130 Proceeds from the phone calls fund the operation of the program. ${ }^{131}$

\section{B. Benefits of Community Notification}

Community notification has gained support for various reasons. First of all, community surveillance of sex offenders augments police surveillance. Under hundreds of watchful eyes, it is more difficult for a sex offender to escape into anonymity. Moreover, this increased surveillance may have a deterrent effect: registered offenders are less likely to commit sex crimes $\mathrm{m}$ the future if they believe their chances of detection are greater. Also, community knowledge of sex offenders' identities inay help to prevent sex offenses, rather than simply help to apprehend sex offenders after an offense has been eommitted. Individuals can tailor their behavior to reduce the risk of victimization by identified sex offenders. Finally, the community inay feel empowered by this information, rather than feel helpless in the face of unknown criminals. For these reasons, community notification has gained tremendous public support in recent years.

Community notification laws require closer examination to determine whether their novel provisions provide a viable and desirable mechamisin for dealing with sex offenders. The next two Parts evaluate the practical and constitutional issues raised by these four models of community notification.

\section{$\mathrm{V}$}

\section{The Practical Limttations of Community Notification}

Community notification is attractive because it promises to correct the failings of registration laws: keeping track of released sex offenders and keeping communities safe from sex crimes. As a practical matter, however, community notification is not a panacea for the problem of sex offenders in local communities. In addition, community notification causes harm to both the community and the offender that outweighs any potential benefit.

\section{A. Inability of Community Notification to Achieve Its Goals}

\section{Community Empowerment or Panic?}

Sex offender community notification laws are premised on the belief that community knowledge about sex offenders will empower residents to protect theinselves. When residents know the identity of convicted sex offenders, they can avoid the identified sex offenders and keep a watchful eye on them.

However, these laws have the potential not only to empower, but also to instill paric. The first three inodels of community notification label sex

130. Id. $\& 290.4(\mathrm{a})(4)(\mathrm{C})($ viii).

131. Id. $\& 290.4(\mathrm{a})(4)(\mathrm{A})$. 
offenders for the community's information. A personal tag of "I am a sex offender" or "He is a sex offender" results from these models. The public is left with nothing more than this label. While residents may be grateful simply to be informed, ${ }^{132}$ this knowledge can also create a feeling of helplessness. ${ }^{133}$

In reality, informed communities can do little more to protect themselves than uninformed communities. If individuals fear abductions from playgrounds or attacks in parking lots, knowing the identity of a sex offender cannot help them to be more vigilant in watching their children or escorting their friends to their cars. Although avoiding a particular individual may create a sense of security, community notification laws do not protect residents from the unregistered or first-time offender. People must still be cautious in supervising and educating their children and in protecting themselves in public.

While some benefits may come from knowing the identity of a registered sex offender, it is not enough to balance out the harms that community notification creates. Community notification laws awaken a community's fear of sex offenders and transform that fear from an abstract anxiety to an identifiable threat. Rather than fearing that some unknown sex offender will victimize the community, people become worried that this particular sex offender will attack agam. Yet for the most part a community can do little to protect itself from a particular sex offender that would be different from protecting itself from sex offenders in general.

The exception lies in those cases where sex offenses are committed, not by strangers, but by acquaintances or even trusted friends. Only $52 \%$ of rapes are committed by strangers. ${ }^{134}$ Thus, a significant number of sex offenses are committed by family members or acquaintances. Notification laws are most helpful im these other cases involving, for example, daycare workers and friends. Knowledge that a particular individual is a convicted child molester encourages parents to prevent their children from coming in contact with this person. But public announcement of a sex offender's identity does more than simply warn people. It places a label on sex offenders which inhibits their interaction in society.

Washington state provides several examples of community notification generating a panic which transformed into vengeance. The most notorious mcident of vindictive behavior occurred in July 1993, when unknown arsonists torched the house of convicted child molester Joseph Gallardo just hours before he was scheduled to arrive there after his release from

132. See Sheila Grissett, Law Keeps Sex Offenders in Public Eye, Tmas-PiCayune, Oct. 24, 1993, at B1, B2 (quoting informed resident, "No one wants one of these perverts next door to them, but it's great that there's a law now to let us know.").

133. See Linda Keene, Warning Signs, SEATtLe TIMES, Sept. 15, 1991, at Pacific 17, 19 (quoting informed resident, "We're sitting targets and we don't like it.").

134. Zawitz et al., supra note 73, at 24. 
prison. ${ }^{135}$ In another case, residents of a small community threw eggs at the residence of a convicted rapist and made death threats to his family. ${ }^{136}$ Other sex offenders are simply left homeless because no landlord will take them. ${ }^{137}$ Sometimes the community outrage and rejection forces the offender out of town-where the cycle begins anew in the next community-or eventually out of the state where the offender is no longer subject to the notification law. ${ }^{138}$

New Jersey exhibited a similar pattern of violence and vengeance against sex offenders within the first few weeks of operation of its community notification law. After being notified by police that a recently paroled sex offender was living at a particular house, a father and son vigilante team broke into the house and attacked a man they thought was the sex offender. ${ }^{139}$ Another convicted sex offender fled New Jersey within days of his release from prison, after the Guardian Angels nounted a leafletting campaign to publicize his presence in the community. Menibers of the Guardian Angels then followed the sex offender to Puerto Rico, where they planned to continue their efforts to notify the public of his whereabouts. ${ }^{140}$

This relocation and bamshing effect exhibited in both Washington and New Jersey is similar to the experience of niany sex offender parolees, who are not formally subject to community notification. Even in states without community notification provisions, the media can pick up parole release data and disseminate it to the community, and it has done so in certain wellpublicized cases. Recently in Califorma, for example, the nedia publicized the scheduled parole of serial rapist Melvin Carter into a suburban collegiate community. ${ }^{141}$ The public outcry agamst Carter's release to the town of Hayward provoked California's governor to transfer Carter's parole to a reniote location. ${ }^{142}$ Similarly, in 1987, paroled rapist Larry Singleton required a police escort to remove him from an apartment building surrounded by scared and angry citizens in Rodeo, California. ${ }^{143}$

While not all communities react in this manner, evidence from Washington state shows that $26 \%$ of sex offenders identified under the com-

135. See Jerry Bergsman, Home Burns on Day Rapist was to Arrive, Seatrme Trmes, July 12, 1993, at Al.

136. See Linda Keene, Legal Dilemma: Rapist's Rights vs. Public's Right to Know, SEATtLE Times, July 13, 1993, at Al, Al4.

137. See Daniel Golden, Sex-cons, Boston Globe MAG., Apr. 4, 1993, at 13, 24.

138. See Keene, supra note 136, at A14.

139. See Malcolm Gladwell, N.J. Law on Released Sex Offenders Proves Problematic, Wash. Post, Jan. 16, 1995, at A6, A7.

140. See Group Takes Megan's Law to Puerto Rico, The Record, Jan. 10, 1995, at A5.

141. See Robert B. Gunnison \& Peter Fimrite, Governor Says Serial Rapist Won't Be Paroled to Hayward, S.F. Chron., Mar. 15, 1994, at Al.

142. See id.

143. See Anthony Marquez, Angry Crowd Forces Parolee to Move, AP, May 26, 1987, avallable in WESTLAW, AP-News Database. 
munity notification law have been subjected to some form of harassment. ${ }^{144}$ The potential for harm to the offender exists, and the potential benefits to the community are negligible. Moreover, harassment is likely to drive a sex offender to move, assume an ahias, or otherwise fail to comply with his community notification duties. In such cases, the benefits of community notification are lost altogether.

The California statute allowing residents to check the sex offense record of a particular person shows promise of achieving the goals of commumity notification without instigating the same panic. A parent hiring a babysitter, for example, can check that person's sex offense history. Dissemmation is limited to specific situations where it is needed. ${ }^{145}$ In all other situations, general caution and awareness will do just as well as knowing whether the particular stranger you are encountering has been convicted of a sex offense.

\section{Addressing Deficiencies in the Registration Laws}

Community notification laws seek to redress, at least in part, the failings of registration laws. Although community notification can remedy some of the problems with registration programs, a few crucial problems remain unresolved.

As Part III demonstrated, the police simply lack the manpower to track offenders and update registration data. Community notification laws may help address this problem by providing extra labor and resources. Essentially, commumity notification laws enlist members of the community as deputy police officers who monitor the moventents and behavior of registered sex offenders. It is a clever plan, augmenting surveillance of sex offenders at a minimal cost.

Notification laws also provide communities with ammumition to prevent sex offenses, rather than simply help police apprehend an offender after commission of the crime. By adjusting their own behavior, concerned citizens can effectively reduce opportunities for sex offenders to commit more crimes. Furthermore, the increased surveillance may act as a deterrent for the offender, who will fear the mcreased likelihood of apprehension in a community aware of his presence.

On the other hand, imcreased surveillance may prompt offenders to move to states with weaker notification provisions. ${ }^{146}$ By creating an incentive for sex offenders to move out of state, notification laws resemble registration laws. Of course, as more states enact community notification

144. See Katherine Seligman, Molesters' 'Scarlet Letter' Bill, S.F. Exammer, Mar. 6, 1994, at A1, Al4 (quoting research at the Institute for Public Policy in Olympia, Washington).

145. The small fee attached to the California telephone program will both finance the registry and deter individuals from frivolously seeking registry information.

146. Or discourage sex offenders from moving to states that do have notification laws. See Grissett, supra note 132, at B3 (quoting parole administrator that Louisiana's community notification law has discouraged some out-of-state paroled sex offenders from moving to Louisiana). 
laws, other states will be encouraged to follow their lead or risk becoming "dumping grounds" for sex offenders.

Finally, community notification laws share the saine primary problein of registration laws: they rely on the cooperation of offenders. Commumity notification does little to remedy the inaccuracy and poor compliance plaguing registration programs. Instead, sex offenders inay be even inore reluctant to register and provide updates on their location if this information will be available to the public. And while community notification may lelp police detect when a sex offender lias inoved without notice, it will not lielp the police discover where the offender lias gone. Indeed, communities who manage to force a sex offender out of town probably have no concern for where he will relocate. The burden thus reinains on the police to track down errant sex offenders.

\section{B. Harmful Side Effects of Community Notification}

\section{The Rejection of Rehabilitation}

By informing the public of a sex offender's presence, community notification laws jeopardize an offender's chances of reintegrating into society and leading a productive life. Community notification laws destroy the anonymity that is crucial to reintegration. A reformed sex offender cannot becoine a productive member of society so long as the commumity treats him as a crimmal. Reintegration requires effort from both parties: the offender must abide by the rules of society, and the community inust allow the offender to enter community life.

One purported premise of our crimmal justice system is to relabilitate criminals. ${ }^{147}$ Reintegration is typically a reward for the rehabilitated offender. ${ }^{148}$ Proponents of community notification laws oppose sex offenders' reintegration into society because they believe that sex offenders are rarely rehabilitated when released from prison, and are likely never to rehabilitate. ${ }^{149}$ Of course, not all sex offenders are incorrigible. Solne respond to therapy or other reliabilitative programs. ${ }^{150}$ Community notification laws fail to discriminate between those capable of reliabilitation and those whose deviancy is permanent. Moreover, a community's rejection of

147. Briscoe v. Reader's Digest, 483 P.2d 34, 41 n.12 (Cal. 1971) (explaining theory behind indeterminate sentencing in California). Although this premise may have been rejectcd long ago, the criminal justice system it created still exists.

148. See id. at 41 ("One of the premises of the rehabilitative process is that the rehabilitated offender can rejoin that great bulk of the community from which he has been ostracized for his antisocial acts. In return for beeoming a 'new man,' he is allowed to melt into the shadows of obscurity.").

149. See, e.g., Chavez, supra note 43, at 16A (quoting state legislator Barbara Alby, "It's not a mattcr of if they are going to commit the act again, they're going to.").

150. See Seligman, supra note 144, at A14. 
the possibility of rehabilitation may become a self-fulfilling prophecy by discouraging offenders from attempting to change their behavior. ${ }^{151}$

\section{Community Notification as Shame Punishment}

In colonial America, shaming mechanisms were familiar forms of punishment. ${ }^{152}$ These punishments imcluded labeling offenders with lettered clothing or branding irons, and shackling offenders in public arenas. ${ }^{153}$ The purpose was to humiliate the offender before the community. Althougl only Louisiana directly imposes public shame in a manner reminiscent of colonial "scarlet letter" pumsshments, all of the commumity notification models are based upon the idea of identifying the offender to the community.

Shaming punishments arose im an era when commumities were closeknit and distinct. ${ }^{154}$ Members of the community knew each other, and could identify outsiders easily. ${ }^{15 s}$ With the demise of shaming and other public displays of punishment, such as public executions, punishment became distanced from the commumity. However, doubts about the effectiveness of incarceration have fueled frustration with conventional imprisoument. ${ }^{156}$ Skeptical of the criminal justice system, the public is clamoring for a return to commumity-based pumishment. ${ }^{157}$

Communty participation is the umifying link in the four models of commumity notification. Each model allows the community to become a participant in the criminal justice process. While none of the models claim to be shaning punishments, but instead parade under the banner of public protection, the similarity to such punishments cannot be accidental. The new laws demonstrate a willingness and desire to draw upon the tradition of shaming.

The self-identification model is the most obvious example of public shaming. Forcing a sex offender to identify himself through postcards and print ads is the modern day equivalent of an afternoon in the pillory in the public square. To be effective, shaming must involve a public display

151. See Golden, supra note 137, at 38 (quoting released sex offender in Washington, "I got the feeling no one cares about me, so why should I care about myself and what I do?').

152. See Toni M. Massaro, Shame, Culture, and American Criminal Law, 89 MrCH. L. Rev. 1880, 1912-15 (1991).

153. See id. at 1913-14; Jon A. Brilliant, Note, The Modern Day Scarlet Letter: A Critical Analysis of Modern Probation Conditions, 1989 Duke L.J. 1357, 1361.

154. See Brilliant, supra note 153 , at 1361 .

155. See David J. Rothman, The Discovery of the Asylum 19 (1990) (describing colonial American communities as insulated self-policing entities that controlled crime by controlling outsiders' entrance to the community).

156. See Massaro, supra note 152 , at 1882.

157. Dissatisfaction with the government's performance in punishing criminals may also motivate people to commit private acts of vengeance. The relationship between community notification laws and vengeance is discussed supra notes $135-140$ and accompanying text. 
which diminishes the offender's standing in the community. ${ }^{158}$ When the community's reaction to the offender is to shun him, harass him, force him out of town, or deny him housing and employment, thus barring hiun from participation in community life, his relationship to the community is severely damaged.

The police discretion model achieves the same results, although through different means. The police, rather than the offender himself, publicize the offender's identity throughout the community. Although the police discretion model does not require the offender's admission of guilt before the community, the community's disapprobation of the offender remains. The public has the same opportunity to shun and harass the offender $\mathrm{m}$ the police discretion model as it does in the self-identification model.

The influence of shaming punishments $\mathrm{m}$ the remaining two models is less obvious, but still significant. The police book and publie request models both attempt to involve the commumity, im a limited way, in the criminal justice process. Public access to sex offender registration data removes the secrecy shrouding criminal punishment. It is a step toward reestablishing the close-knit community. Thus, all of the community notification models appeal to the public's desire for a sense of community and in this way are reminiscent of sliaming punishments.

Analyzed from the perspective of shaming, the telephone request community notification model differs in one important way from the other three models. The first three nodels introduce individuals to the community as sex offenders, either by the offender himself, a posted police bulletin, or a police book that identifies the offender. The public request model is slightly different. It allows people to gather more information about known mdividuals rather than introducing a previously unknown individual as a "sex offender." By placing a one-dinensional label on sex offenders without a context, the first three models expose an offender to general humiliation. In contrast, the public request model provides a context, which reduces the labeling effect and increases the possibility that the public will tailor its adverse reactions to the offender to situations where the offender could actually jeopardize the public's safety.

A return to shaming punishments, as a reaction to the failure of the prison system, is not necessarily undesirable. In certain situations, shaming punishments may be an appropriate way to rehabilitate and deter. ${ }^{159}$ But in the context of sex offenses, where the community's reaction is highly emotional, and sometimes violent, shaming is inappropriate.

158. See Massaro, supra note 152, at 1902.

159. See Rosalind K. Kelley, Comment, Sentenced to Wear the Scarlet Letter: Judicial Innovations in Sentencing-Are They Constitutional?, 93 Drck. L. Rev. 759, 787 (1989) (recommending that scarlet letter sentences would be most appropriate for "middle-low risk" offenders). 
A true shame punishment would attempt to shape the offender's moral character - to shame him into conforming to the community's inoral code. Advocates of community notification, however, reject the notion that sex offenders can rehabilitate. ${ }^{160}$ Shaming thus becomes merely an outlet for the community's rage.

\section{VI}

\section{Community Notification as Punishment}

Even if there were coinpelling policy justifications for community notification laws, such laws are probably unconstitutional. The public stigma inflicted by community notification laws may violate the Eighth Amendment prohibition against cruel and unusual punishment. This Part weighs each notification model agamst Eighth Amendment requirements.

Given the recent genesis of community notification laws, judicial opinion on their constitutionality is sparse. Thus, the primary resource for addressing their constitutionality is state courts' analyses of sex offender registration statutes. The arguments used to advance or challenge these statutes provide excellent models for analyzing community notification laws.

Before conducting an Eighth Amendment analysis, however, courts must address the prehmmary issue of whether registration or notification provisions constitute punishment or mere regulation. Only if a court concludes that a law is a punishment can it consider whether the law is cruel and unusual.

\section{A. Punishment or Regulation?}

\section{Current Case Law}

In Kennedy v. Mendoza-Martinez, the Supreme Court formulated its current test for determining whether a particular statute is punitive or regulatory. ${ }^{161}$ Every court that has considered the nature of a sex offender registration or community notification statute has applied, or at least addressed the applicability of, the Mendoza-Martinez test. But despite their use of the

160. See supra notes $149-151$ and accompanying text.

161. 372 U.S. 144, 168-69 (1963).

A more recent Supreme Court decision has been advocated as a successor to Mendoza-Martinez. In Astway v. Attorney General, 876 F. Supp. 666 (D.N.J. 1995), both parties argued that the proper case for determining whether New Jersey's community notification law constituted punishment was Austin v. United States, 113 S. Ct. 2801 (1993). Artway, 876 F. Supp. at 673 n.8. The court did not accept the argument that Austin had supplanted Mendoza-Martinez as the appropriate test, and decided that, at least in the eontext of an ex post facto analysis, Mendoza-Martinez was applicable. Id.

Austin itself did not assert that its analysis should supersede the Mendoza-Martinez test in all cases. In fact, the Austin court was careful to note that its decision dealt only with the Excessive Fines Clause of the Eighth Amendment. Austin, $113 \mathrm{~S}$. Ct. at 2806 n.6. Thus, it appears that Mendoza-Martinez remains the appropriate test to apply in considering whether sex offender community notification laws constitute punishment under the Cruel and Unusual Punishment Clause of the Eighth Amendment. 
same seven-factor test, courts are split fairly evenly in the conclusions they reach.

\section{a. The Mendoza-Martinez Test}

In Mendoza-Martinez, the Supreine Court designed a detailed analysis to highlight the distinction between punishment and regulation. The oftquoted test consists of seven factors:

[1] Whether the sanction involves an affirmative disability or restraint, [2] whether it has historically been regarded as a punishinent, [3] whether it comes into play only on a finding of scienter, [4] whether its operation will proinote the traditional ains of punishment-retribution and deterrence, [5] whether the behavior to which it applies is already a crime, [6] whether an alternative purpose to which it inay rationally be connected is assignable to it, and [7] whether it appears excessive in relation to the alternative purpose assigned .... ${ }^{162}$

The Court cautioned that all of the above factors were "relevant to the inquiry, and inay often point in differing directions."163 Finally, the Court limited use of the seven-factor analysis to when "conclusive cvidence of congressional intent as to the penal nature of a statute" is lacking. ${ }^{164}$

\section{b. Application of Mendoza-Martinez in Registration and Community Notification Cases}

In applying the Mendoza-Martinez test to registration and community notification laws, courts have differed both in their interpretations of the test, and in their perceptions of the statutes in question. Consequently, the courts have not arrived at a consensus as to whether registration and coininunity notification laws are regulatory or punitive.

\section{i. The Argument for Regulation}

Three states have issued thoughtful opinions concluding that sex offender registration or community notification laws are regulatory rather than punitive: Arizona, Illinois, and Washington. Though the Arizona and Illinois Supreine Courts addressed registration laws, ${ }^{165}$ and the Washington Supreine Court evaluated a community notification law, ${ }^{166}$ the three opin-

162. Mendoza-Martinez, 372 U.S. at 168-69 (footnotes omitted).

163. Id. at 169.

164. Id. A later Court opinion clarified that a court should apply Mendoza-Martinez even if the legislature clearly intended to establish a civil penalty, rather than a criminal penalty, because a civil statute that is so punitive in effect may negate the expressed intentions of the legislature. United States v. Ward, 448 U.S. 242, 248-49 (1980).

165. See State v. Noble, 829 P.2d 1217, 1218 (Ariz. 1992); People v. Adams, 581 N.E.2d 637, 639 (Ill. 1991).

166. See State v. Ward, 869 P.2d 1062, 1065 (Wash. 1994). 
ions considered many of the same issues and thus are susceptible to comparison.

In People v. Adams, ${ }^{167}$ the Illinois Supreme Court refused to apply the Mendoza-Martinez test. The Court held that the legislature clearly intended the statute to be regulatory in nature, ${ }^{168}$ and refused to consider the Mendoza-Martinez factors because conclusive evidence of legislative intent was available. ${ }^{169}$ In fact, the Adams court was wrong; Mendoza-Martinez held that the seven-factor test is unnecessary only when conclusive evidence of a penal intent is available. ${ }^{170}$ Nevertheless, the Adams court did hold that some inquiry into the "severity of the disability" imposed on the offender was necessary. ${ }^{171}$ The court concluded that, compared to continued incarceration, registration inposed a relatively light burden on sex offenders, and thus did not constitute punishment for purposes of the Eighth Amendment. ${ }^{172}$

The Washington and Arizona courts applied the Mendoza-Martinez test in their analyses, but only after they had resolved the threshold issue of legislative intent. In State v. Ward, the Washington Supreme Court found that the state legislature had a clear regulatory purpose in enacting its coinmunity notification statute. ${ }^{173}$ While the court stated that such a finding was sufficient under Mendoza-Martinez to conclude that the statute was regulatory, ${ }^{174}$ it asserted that the inquiry into legislative purpose should be weighed against the effects of the statute, and that the Mendoza-Martinez test was the proper method to determine the relevant effects of the statute. ${ }^{175}$ Thus, although the Ward court also misinterpreted the MendozaMartinez requirements regarding legislative intent, it properly applied the test in the end.

Finally, in State v. Noble, the Arizona Supreme Court could not find a clear punitive or regulatory intent behind Arizona's sex offender registration statute, and thus applied the Mendoza-Martinez test. ${ }^{176}$ The Noble court concluded that the statute was regulatory, but admitted that its deci-

167. 581 N.E.2d 637 (111. 1991).

168. Id. at 640-41 (citing 84th IIl. Gen. Assem., House Proceedings, June 23, 1986, at 208).

169. Id. at. 641 .

170. Mendoza-Martinez, 372 U.S. at 169.

171. Adams, 581 N.E.2d at 640 (citing Trop v. Dulles, 356 U.S. 86, 96 (1958)).

172. Id. at 640-41. As additional evidence of the statute's nonpenal nature, the court pointed to the lack of remedial measures directed at sex offenders who target children. Id. at 641. If the statute was intended as a punishment for sex offenders, rather than a regulation to protect children, the court would expect to see some focus on correcting pedophiles' behavior. Id. This argument is interesting because correcting offenders' behavior may offer more protection for children, and thus better enhance the regulatory purpose of the statute, than registering unreformed sex offenders. However, because rehabilitation is often considered a goal of punishment, correctional intentions could signify that the statute was penal in nature.

173. 869 P.2d 1062, 1068-69 (Wash. 1994).

174. Id. at 1068.

175. Id.

176. 829 P.2d 1217, 1221 (Ariz. 1992). 
sion was "close."177 Under the first element of the test, the court found that the registration requirement "does not affirmatively inhibit or restrain an offender's movement or activities."178 Hcre, the court focused only on the availability of registration information to non-law enforcement personnel and concluded that the impact of the registration law on such availability was "marginal."."179

Turning to the second element, the Arizona Supreme Court found that registration traditionally has been viewed as punishment. The court referred to the "ignomimious badgc" of sex offender registration, ${ }^{180}$ and the oppressiveness of permanent government surveillance. ${ }^{181}$ Two factors convinced the court that the stiginatizing punitive effect on the offender was not that great: the existence of provisions limiting access to registry information, and the independent availability of much of the information contained in the registry. ${ }^{182}$

The court briefly considered the fourth eleinent, finding that registration has a deterrent effect on sex offenders because they are more likely to be apprehended if the police know their whereabouts. ${ }^{183}$ The court did not analyze either the third or fifth element of the Mendoza-Martinez test.

Finally, considering the sixth and seventh elements together, the Noble court found that the registration requirement was not excessive in relation to its nonpunitive purpose: assisting law enforcement imvestigations of sex offenses. ${ }^{184}$ The court emphasized that registration does not single out registrants for police harassment, but is a tool for law enforcement personnel that does not abridge the constitutional rights of any individual listed in the registry. ${ }^{185}$ Furthermore, as applied to those who have committed sex offenses agamst children, such as the defendant in Noble, the court found that the registration requirement was not excessive given "the importance of locating and apprehending recidivists."186

Weighing the results from each of these analyses, the court narrowly concluded that Arizona's sex offender registration law was not punitive. The statute's overriding purpose to aid law enforcement personnel in locatmg child sex offenders, and the relative confidentiality of the registry infor-

177. Id. at 1224 .

178. Id. at 1222 (quoting State v. McCuin, 808 P.2d 332, 339 (Ariz. Ct. App. 1991), one of two appellate court opinions giving rise to Noble).

179. Id. Another statute allowed certain non-law enforcement personnel access to nearly all the same information. Thus, the registration statute did very little to increase access to such information. Id. \& n.8.

180. Id. (quoting In re Birch, 515 P.2d 12, 17 (Cal. 1973)).

181. Id. at 1223 (citing Weems v. United States, 217 U.S. 349,366 (1910)).

182. Id.

183. Id.

184. Id. at 1224 .

185. Id. at 1223 .

186. Id. at 1224 \& n.10 (citing recidivism studies by Romero \& Williams, and Groth et al.); see supra notes $47 \& 54$. 
mation, tipped the scales in favor of finding that the statute was regulatory in nature. ${ }^{187}$ That the court placed such emphasis on the confidentiality of registration information suggests that it might have reached a different conclusion if the Arizona statute had required some form of community notification.

Though the Washington Supreme Court in State v. Ward cited Noble with approval, it did not share the same concerns about confidentiality. In evaluating Washington's community notification law under MendozaMartinez, the Ward court concluded that the law was clearly regulatory.

Considering the first element of the test, the court found that registration and the potential for publication of this information to the community did not constitute an affirmative disability or restraint. Registration does not restrict movement in any way, the court stated, nor does it require the offender to divulge information that is not already on file with some state agency for other purposes. ${ }^{188}$ The court found the actual burden of filling out the initial registration form and subsequent forms upon changing residence insignificant. ${ }^{189}$

As for the notification provisions of the statute, the court held that the limits on the disclosure of registration information indicated a clear legislative intent to use disclosure only for regulatory purposes. ${ }^{190}$ Thus, the court found that any burden on the offender which resulted from disclosure was not a punishment for his crime, but a necessary precaution against potential danger. ${ }^{191}$ The court argued that any public stigma that attached to the offender was not the result of registration or community notification, but was a consequence of "private reactions to the crime by members of the general public."192

Under the second element of the Mendoza-Martinez test, the Ward court explicitly rejected Noble's conclusion that registration traditionally has been viewed as punitive. ${ }^{193}$ The court noted that "[r]egistration is a traditional governmental method of making available relevant and necessary information to law enforcement agencies."194 The court did not make any inquiry under the third or fifth elements of the test.

The court also found that registration was not punitive under the fourth element of the Mendoza-Martinez test. While acknowledging that registration could act as a deterrent, the court einphasized that the primary purpose of the statute is to aid law enforcement agencies in protecting their commu-

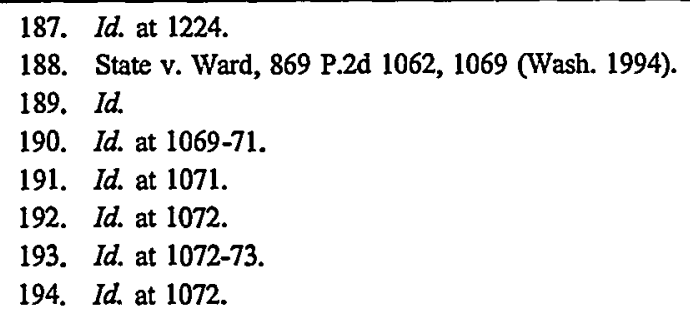


nities. ${ }^{195}$ Although the court found that the secondary, deterrent effect of registration benefited the community, it declined to hold that this benefit constituted punishment of the offender. ${ }^{196}$

Coinbining the last two factors of the test, the court found that community notification is not excessive in relation to its nonpunitive purposes. Because the offender does not lose any of the constitutional safeguards which protect him from intrusive law enforcement practices, registration does not unduly burden offenders. ${ }^{197}$ If a registrant is the focus of a sex offense investigation it is a result of his conviction, not a consequence of his registration status. ${ }^{198}$

Fimally, the court rejected the argument that registration places a "lifelong badge of infamy" on the offender which outweighs the statute's regulatory purpose. ${ }^{199}$ Washington's registration law requires only class A felons to register for life; other classes of criminals are relieved from registration after a set period of years. ${ }^{200}$ In any case, an offender may petition for removal of the registration duty upon a showing of rehabilitation. ${ }^{201}$ The potential for dissemination of registry information to the public did not modify the court's analysis at all. In sum, the court conclided that Washington's sex offender registration statute, despite its potential for public disclosure of the offender's identity, was not punitive. ${ }^{202}$

\section{ii. The Argument for Punishment}

Over a decade ago, the California Supreme Court issued a strong opinion holding that registration is a punishment, rather than a regulation. ${ }^{203}$ Since then, other state courts have also classified community notification as punishment, although without any detailed analysis of the issues. ${ }^{204}$ In the

195. Id. at 1071.

196. Id. at 1073.

197. Id.

198. Id.

199. Id.

200. Id. at 1073-74.

201. Id. at 1074 .

202. Ward was the first decision to examine thoroughly a community notification law to determine whether the law was punitive or regulatory. Prior to Ward, Louisiana courts had confronted the validity of community notification, but had not focused their analysis on whether it was a punishment. See Francois v. State, No. 394,049, ship op. at 2 (Dist. Ct. La. May 17, 1993) (oral reasons for judgment) (on file with author); State v. Payne, 633 So. 2d 701, 702-03 (La. Ct. App. 1993). One Louisiana court had considered a challenge to the state's "scarlet letter" law, but dismissed the offender's Eighth Amendment argument by stating, "[c]ruel and unusual punishment has to do with sentencing. This is not a sentencing, this is a parole." Francois, No. 394,049, slip op. at 2. While the Louisiana court did not hold that community notification was regulatory, it denied any punitive effect community notification may have on the offender.

203. In re Reed, 663 P.2d 216, 220 (Cal. 1983).

204. See State v. Babin, 637 So. 2d 814, 823-25 (La. Ct. App.), cert. denied, 644 So. 2d 649 (La. 1994); State v. Payne, 633 So. 2d 701, 702-03 (La. Ct. App. 1993), cert. denied, 637 So. $2 \mathrm{~d} 497$ (La. 1994); State v. Douglas, 586 N.E.2d 1096, 1098-99 (Ohio Ct. App. 1989). 
past year, federal courts in both Alaska and New Jersey have determined that their respective community notification laws constitute punishment. ${ }^{205}$

California addressed the punitive issue explicitly in In re Reed. ${ }^{206}$ In that case, a petitioner challenged the registration requireinent as cruel and unusual punishment as applied to persons, like himself, convicted of "soliciting lewd and dissolute conduct."207 The Cahfornia Supreme Court did not inquire into legislative intent, but proceeded directly to a MendozaMartinez analysis to determine whether the statute was punitive or regulatory. ${ }^{208}$

First, the court found that registration was an "affirmative disability or restramt" because it placed a lifelong burden upon the offender. ${ }^{209}$ Registration subjects the offender to a lifetime of police surveillance, with increased focus every time a sex offense is committed in his area. ${ }^{210}$ This increased focus may lead to actual restramt by the police if a registered sex offender is summoned for a line-up identification simply because he is a registered sex offender. ${ }^{211}$ The court noted that even though the offender could terminate the requirement to register under California Penal Code section 1203.4, his initial registration data would not be expunged from police records. Thus, personal information such as his name, photograph, and fingerprints would always be readily available to the police. ${ }^{212}$

Turning to the second element, the Reed court suggested registration may not have "historically been regarded as punishment."213 However, the court noted that this question is not dispositive, and that methods of punishment other than the traditional penalties of fines, imprisonment, and death

205. See Artway v. Attorney General, 876 F. Supp. 666, 692 (D.N.J. 1995); Rowe v. Burton, No. A94-206, slip op. at 18-19 (D. Alaska July 27, 1994) (unpublished deeision) (on file with author).

206. 663 P.2d 216 (Cal. 1983). Reed challenged the registration statute under the state's cruel and unusual punishment clause in Article I, Section 17 of the California Constitution. Id. at 217.

207. Id. at 216 (internal quotations omitted). Reed engaged in conversation with an undercover vice officer at the urinals in a public restroom, and briefly masturbated in the officer's presence. Id. at 221. Although Reed denied soliciting the police officer, id., he was convicted of soliciting "lewd or dissolute conduct" in violation of California Penal Code section 647(a). Id. at 216.

208. Id. at 218-19 (quoting Mendoza-Martinez, 372 U.S. at 168-69).

209. Id. California's registration requirement imposes a lifelong duty to register. See CAL. Penar CODE $\S 290$ (no provision on termination of duty to register); Kelly v. Municipal Court, 324 P.2d 990, 992 (Cal. App. 1958) (finding duty to register under CAL. PENAL CODE $\S 290$ is "a burden which the convicted person carries with him until his dying day").

210. The court quoted its previous opinion that "the ignominious badgc [of sex offender registration] carried by the convicted sex offender can remain for a lifetime." Reed, 663 P.2d at 218 (quoting In re Birch, 515 P.2d 12, 17 (Cal. 1973)). The context in Birch clearly establishes that the "ignominious badge" is perpetuated by "continual police surveillance" and repeated police investigations, not from the stigma of the conviction itself. Birch, 515 P.2d at 17.

211. Reed, 663 P.2d at 218.

212. Id. at 218-19.

213. Id. at 219 . 
are "constitutionally suspect." 214 The court also emphasized the severity of the penalty of permanent police surveillance. ${ }^{215}$

Because the crime at issue required "lewd intent" and "specific sexual touching," the court found that the third element of scienter, or guilty knowledge, was satisfied here. ${ }^{216}$ Likewise, the court quickly concluded that the fourth element of punitive aim was fulfilled because the legislature clearly intended to deter recidivism through registration. ${ }^{217}$ Also, because registration applied only to conduct which is already criminal, it satisfied the fifth element of the Mendoza-Martinez test. ${ }^{218}$ Finally, the court found under the last two elements that, although the legislature may have intended registration to serve a purpose other than punishment-i.e., to assist criminal investigations of sex offenses-registration is an excessive penalty in relation to this purpose. ${ }^{219}$

Other states have considered their community notification and registration laws to be punitive, although they have not addressed the issue explicitly. In State $v$. Douglas, an Ohio appellate court simply assumed that registration was punitive. 220 It nonetheless determined that the state's registration requirements were not cruel and unusual punishment. ${ }^{221}$ Similarly, im State v. Payne, a Louisiana appellate court held that community notification as a special condition of probation violated the ex post facto clauses of the federal and Louisiana constitutions. ${ }^{222}$ This conclusion necessarily meant that the court considered community notification a punishinent. 223

Two very recent federal cases lend reasoned support to the conclusion that community notification laws are punishment. In Rowe v. Burton, a federal district court in Alaska considered whether the state's community

214. Id. (citations omitted).

215. Id. (quoting Weems v. United States, 217 U.S. 349, 366 (1910) ("[N]ot being able to change his domicile without giving notice to the 'authority immediately in charge of his surveillance,' $\ldots$ he is subject to tormenting regulations that, if not so tangible as iron bars and stone walls, oppress as much by their continuity, and deprive of essential liberty.")).

216. Id.

217. Id.

218. Id.

219. Id. at 219-20. The court pointed to the ineffectiveness of the registration scheme to assist in apprelending suspects to support its argument. Id. at 219-20 n.7.

220. 586 N.E.2d 1096, 1097-99 (Ohio Ct. App. 1989).

221. Id.

222. 633 So. 2d 701, 702-03 (La. Ct. App. 1993), cert. denied, 637 So. $2 d 497$ (La. 1994). Another Louisiana court followed Payne the next year, and invalidated the application of community notification to a probationer who committed his crimes before Louisiana enacted its commuuity notification law. State v. Babin, 637 So. 2d 814, 824 (La. Ct. App.), cert. denied, 644 So. 2d 649 (La. 1994).

223. The Payne court took an unusual approach to its determination that community notification was a violation of the prohibition against ex post facto laws. It found that the notification statute "exposes defendant to additional penalties for his criminal conduct," because "should [he] fail to comply with these provisions ... he is exposed to a fine, imprisonment, or both." Payne, 633 So. 2d at 703 . Thus, the court did not addrcss whether the act of community notification itself inflicted punishment on the offender, which is the focus of this section of the Comment. 
notification law violated the ex post facto clause of the U.S. Constitution. ${ }^{224}$ In addressing the question of whether the statute was punitive, the court found an express legislative intent to protect the public, but rejected the argument that legislative intent should be dispositive. ${ }^{225}$ The court proceeded to engage in a Mendoza-Martinez analysis.

First, the Rowe court concluded that community notification is an affirmative disability in that it "may subject registrants . . . to public stigma and ostracisin that would affect both their personal and professional lives."226 Second, the court found that community notification was not historically viewed as a punishment. ${ }^{227}$ Because the provisions of the law were imposed only after a finding of scienter, the court held that the third element of the test was satisfied.228

Fourth, looking again to the probable ostracism and harassment that would result from community notification, Rowe concluded that community notification did serve a retributive, and therefore punitive, purpose. ${ }^{229}$ Fifth, the court found that the statute applied only to conduct that was clearly already a criine. ${ }^{230}$

The Rowe court accepted that the statute was rationally related to the protection of society, and thus found that the sixth element of MendozaMartinez supported a finding that the law was regulatory. ${ }^{231}$ But in considering the final element of the analysis, the court held that community notification was an overly broad mechanism for protecting the public, and thus concluded that the law was punitive. ${ }^{232}$

In the second case, the U.S. District Court of New Jersey found that the community notification provisions of the infamous "Megan's Law" violated the ex post facto clause of the U.S. Constitution. ${ }^{233}$ In Artway $v$. Attorney General of New Jersey, the court acknowledged the legislature's stated regulatory ain in enacting "Megan's Law," but asserted that it "must focus on the practical purpose and effect of the statute and reacli an independent conclusion as to its true nature."234 The court eventually performed a Mendoza-Martinez analysis, but not before identifying other issues relevant to the plaintiff's claims of cruel and unusual punishment-

224. Rowe v. Burton, No. A94-206 (D. Alaska July 27, 1994) (unpublished decision) (on file with author).

225. Id. at $8-10$.

226. Id. at 11 .

227. Id. at 12 .

228. Id. at $12-13$.

229. Id. at 14 .

230. Id. at 15.

231. Id.

232. Id. at 15-17.

233. Artway v. Attorney General, 876 F. Supp. 666, 692 (D.N.J. 1995).

234. Id. at 673. 
the right to privacy, bills of attainder, and double jeopardy-issues that supplement the Mendoza-Martinez analysis. ${ }^{235}$

Artway focused on the publicity generated by community notification laws im its discussion of the first Mendoza-Martinez factor. Acknowledging that criminal records have always been public, the Artway court stressed that public dissemmation of information that identifies the offender, and that requires no specific inquiry on the part of the cominunity, goes far beyond any previous laws. ${ }^{236}$ Given this invasion of privacy, and the potentially debilitating effects such dissemmation has upon the offender's ability to lead a normal life in the community, the Artway court held that community notification is an affirmative disability or restraint. ${ }^{237}$

Referring to the biblical story of the mark of Cam, the Artway court concluded that community notification has been historically regarded as a punishment, satisfying the second element of Mendoza-Martinez. ${ }^{238}$ Turning to the third element of the test, the court found that supporters of "Megan's Law" justified it not on a finding of scienter, but on the purportedly high recidivism rates of sex offenders. ${ }^{239}$ Without making any explicit connection between recidivisin and regulation, the court found that the recidivism justification weighed in favor of the regulatory nature of the law. ${ }^{240}$

Under the fourth element of the test, the Artway court dccided that community notification had a deterrent effect, but refused to find a retributive effect as well. While the law was deterrent by design, it was not official retribution because the community's independent reactions, not the government's, constituted the harmful effects on the offender. ${ }^{241}$ Nonetheless, the presence of deterrence was enough for the court to conclude that this factor weighed in favor of punishment. ${ }^{242}$ The court also concluded that sex offenses are already crimes, and that this indicated, under the fifth element, that the law was punishment. ${ }^{243}$

Under the sixth element of the test, Artway found that the law had a nonpunitive purpose of protecting the public by increasing community awareness of sex offenders. ${ }^{244}$ However, the court found that this purpose was "imextricably linked to deterrence," and thus could not properly be labelled an alternative, nonpunitive purpose. ${ }^{245}$ The court concluded that

235. Id. at 679-85.

236. Id. at $688-89$.

237. Id. at 689 .

238. Id. (citing Genesis 4:15).

239. Id. at 690 . The court expressed reservations regarding the validity of the recidivism rates offered by the law's supporters, but deferred to the legislature's findings on this matter. Id.

240. Id.

241. Id. at $690-91$.

242. Id. at 691 .

243. Id.

244. Id.

245. Id. at 691-92. 
public dissemination of sex offender information went "beyond . . . traditional justifiable law enforcement objectives," and thus, under the seventh factor, was excessive in relation to its stated regulatory purpose. ${ }^{246}$

\section{Identifying the Appropriate Test}

The cases discussed above demonstrate the disagreement over which facts about a statute are applicable to the seven-factor Mendoza-Martinez test. However, most striking is the difference in interpretation of and regard for the consideration of legislative intent. In Mendoza-Martinez, the U.S. Supreme Court laid out a sensible rule for dealing with legislative intent, but few courts have accurately applied it.

Mendoza-Martinez explicitly held that its seven-factor test should be used only "[a]bsent conclusive evidence of congressional intent as to the penal nature of a statute."247 Thus, even if a legislature clearly stated that it intended a regulatory statute, a court should perform the seven-factor analysis because the legislature did not clearly express a penal intent. ${ }^{248}$ Deferring only to an expressed penal intent removes any concerns regarding manufactured legislative history. ${ }^{249}$ A legislature has no incentive to call a regulatory statute penal, because the required criminal procedural safeguards would liamper strict enforcement of the statute. On the other hand, the legislature does liave an incentive to label a penal statute regulatory because relaxed procedural safeguards allow for inore efficient enforcement. Thus, by accepting a penal legislative label, and requiring greater scrutiny of a regulatory or ambiguous label, the Mendoza-Martinez test recognizes these realities.

If a legislature ever admitted punitive aims in enacting a community notification law, the Mendoza-Martinez analysis would be unnecessary, and a court could jump directly into an Eighth Amendment analysis. However, none of the statutes examined in this Comment have an express punitive intent. All are therefore subject to the seven-factor Mendoza-Martinez test.

246. Id. at 692 .

247. Kennedy v. Mendoza-Martinez, 372 U.S. 144, 169 (1963) (emphasis added).

248. See Schall v. Martin, 467 U.S. 253, 269 (1984) (interpreting Mendoza-Martinez to require inquiry into factors other than intent only "[a]bsent a showing of an express intent to punish"); United States v. Ward, 448 U.S. 242, 249-50 (1980) (applying Mendoza-Martinez test to determine whether effects of statute negate its expressed regulatory intent).

249. For an expression of concern about the manufacture of legislative history, and other concerns about reliance on legislative intent, see Maria Foscarinis, Note, Toward a Constitutional Definition of Punishment, 80 Colum. L. Rev. 1667, 1673 \& nn.42-43 (1980). 


\section{Community Notification Is Punishment}

This section applies the Mendoza-Martinez test ${ }^{250}$ to eacli of the four community notification models. ${ }^{251}$ The analysis draws upon the cases described im the previous sections, and critiques the courts' holdings in those cases.

\section{a. Self-Identification}

The self-identification model imposes an affirmative disability under the Mendoza-Martinez test. The model requires the offender to identify himself to the community througli postcards, advertisements, and signs. Unlike a registration requirement under which the state provides the offender with the necessary forms, the state does not provide a list of neighbors, a stack of postcards, or a roll of stamps. The offender must expend a significant amount of time and money to fulfill his legal obligation. ${ }^{252}$ While the statute does not pliysically restram the offender, it undoubtedly burdens him with a tedious, huniliating, and potentially expensive task.

Self-identification lias traditionally been regarded as a form of punishment, ${ }^{253}$ and also satisfies the traditional aims of punishment: retribution and deterrence. ${ }^{254}$ Retribution is often cliaracterized as revenge, ${ }^{255}$ but it is more precisely a moral condemnation by society of an offender's behavior-unlike revenge, which is a personal emotional response to wrongdoing. ${ }^{256}$ Only the state can impose punishment on an offender as retribution

250. This analysis will, as many courts in the sex offender registration and notification context have done, skip over the third, fifth, and sixth elements of the Mendoza-Martinez test. Obviously, the sex offenses to which community notification would apply are already crimes, satisfying the fifth element. Although not all sex offenses to which such laws might apply require a finding of scienter, e.g., statutory rape, this analysis will assume that each community notification model satisfies the third element as well. As discussed in Part IV, the nonpunitive purpose of community notification laws is the protection of the community. This will serve as an answer to the sixth element in each of these analyses.

251. See supra notes 114-131 and accompanying text.

252. See, e.g., Tyler, supra note 3, at A6 (reporting that one offender in an urban arca spent $\$ 51$ to mail 270 handwritten postcards to neighbors in order to comply with law). For some offenders, the financial burden of notification prohibits them from complying. Letter from Sherry Johnson, Legislative Assistant to La. State Rep. Pete Schneider, to author (Mar. 4, 1994), attachment, Sex Offender Statistics (on file with author). As of November 1993, nearly five perccnt of sex offenders required to abide by the Act did not have enough money to comply with notification. Id. (22 out of 442 unablc to afford postage, etc.) Louisiana promises to work with these indigent offenders, e.g., by negotiating loans, to enable them to fulfill their obligations. Id. As of May 17, 1994, the state had lowered the figure for noncompliance due to indigence to just under two percent. Telcphone interview with Sherry Johnson, Legislative Assistant to La. State Rep. Pete Schneider (Oct. 24, 1994) (only 11 out of 562 unable to afford notification).

253. See supra notes $152-155,238$ and accompanying text.

254. These are the two aims identified by the Mendoza-Martinez court. Mendoza-Martinez, 372 U.S. at 168.

255. See generally Susan Jacoby, WLd Justice: The Evolution of Revenge (1983).

256. See Jean Hampton, Correcting Harms Versus Righting Wrongs: The Goal of Retribution, 39 UCLA L. REv. 1659, 1691 n.49 (1993). 
for his bad act. ${ }^{257}$ However, requiring the offender to identify himself exposes him to society's moral disapprobation. The public's state-mduced condemnation is therefore retributive. ${ }^{258}$ More clearly, self-identification acts as a deterrent. Sex offenders will likely consider the greater chance that they will be apprehended for their crimes while under such surveillance. Moreover, it is conceivable that the promise of years of community surveillance in addition to imprisonment may be more threatening to a potential sex offender than a prison term. Thus, self-identification deters both convicted offenders from committing further crimes and potential offenders from committing their first.

Fimally, self-identification is an excessive means of protecting the public. While the community may use its knowledge of an offender's identity to protect itself from his crimmal behavior, it can also use this knowledge to condemn and ostracize him. These effects are not rationally related to the goal of public protection. Thus, self-identification is clearly punishment.

\section{b. Police Discretion}

This section challenges the analysis of the police discretion model in Ward, in which the court found that Washington's community notification statute was not punitive. This section also draws upon the analyses in Artway and Rowe, where the police discretion model was also at issue.

In its discussion of the first element of the Mendoza-Martinez test, the Ward court found that the language of the statute severely circumscribed police discretion in notifying a community about a released sex offender. However, the court's focus on statutory language was misplaced. As the court itself noted, the Mendoza-Martinez test was designed to coinpare the effects of a statute with its stated purposes. ${ }^{259}$ Yet by dissecting the legislative policy behind the statute, and by einphasizing how this policy limited the discretion of police, the Ward court focused on purpose instead of effect. $^{260}$ A proper analysis would have examined what disabilities or restraints actually resulted from a police decision to release information about a registered sex offender.

As with the self-identification model, an offender under the police discretion model is not physically restrained in any way. However, the community's likely response to the release of his registration information would

257. See Lester H. Hunt, Punishment, Revenge and the Minimal Functions of the State, in 1 Understandno Human Emotions 80-81 (Fred D. Miller, Jr. \& Thomas W. Attig, eds. 1979).

258. It also borders on being vengeful. By forcing the offender to identify himself to the community, the state seems to invite private reactions against the offender. See supra notes 132-138 and accompanying text.

259. State v. Ward, 869 P.2d 1062, 1068 (Wash. 1994) ("We turn to the factors listed in [MendozaMartinez] for assistance in determining whether the effect of a statute is regulatory or punitive.").

260. Id. at 1070 ("The Legislature's pronouncement evidences a clear regulatory intent to limit the exchange of relevant information to the general public to those circumstances which present a threat to public safety.") (emphasis added). 
hinder his reintegration into society, as Artway and Rowe recognized. ${ }^{261}$ Community hostility and violence often prevent the offender from finding or maintaining a residence and a job. ${ }^{262}$ Ward atteinpted to argue this point to the Washington Supreme Court, bringing in newspaper clippings with accounts of harsh community reaction to offenders whose identities had been released by the police, ${ }^{263}$ but the court was unreceptive.

Releasing the identities of convicted criminals has not traditionally been regarded as punishment. The traditional shame punishments of the colomal era required the criminal himself to be the mode of communication to the community of his criminal status. However, surveillance has long been regarded as a punishinent by the U.S. Supreme Court, ${ }^{264}$ and community notification is essentially a prescription for community surveillance.

Like self-identification, community notification by the police also furthers traditional aims of punishment. Once a sex offender is identified, whether by the police or himself, he becoines the direct object of community conteinpt, which has both retributive and deterrent effects. ${ }^{265}$

Finally, community notification, even if limited by police discretion, is excessive in relation to its nonpunitive purpose of protecting the community. The awareness that a particular sex offender is living in the community does more than help residents protect themselves. It gives thein ammunition with which to harass and disparage the offender. ${ }^{266}$

\section{c. The Police Book and Telephone Request Models}

The police book and public access by telephone request models are the most difficult to analyze because they are as yet untested. Both differ significantly from the previous two nodels because there is no public announcement of an offender's identity. Instead, an individual citizen gains access to this knowledge at his or lier own initiative.

However, this feature inerely limits-not eliminates-the potential for disabling harassment. Though some provisions atteinpt to prevent a resident from obtaining information and publicizing it, or worse, using it to harm the offender verbally, physically, or financially, ${ }^{267}$ it is unclear how

261. See supra notes $226 \& 237$ and accompanying text.

262. See Keene, supra note 136, at A1, Al4 (recounting several instances where sex offenders were forced from their homes and/or jobs by community pressure and violence after their identities were released to the public).

263. Ward, 869 P.2d at 1069.

264. Weems v. United States, 217 U.S. 349, 366 (1910), cited in State v. Noble, 829 P.2d 1217, 1223 (Ariz. 1992); In re Reed, 663 P.2d 216, 219 (Cal. 1983).

265. See State v. Taylor, 835 P.2d 245, 250 (Wash. App. 1992) (Agid, J., dissenting); see also supra notes 254-258 and accompanying text.

266. See text aceompanying notes 135-144.

267. There is a provision in the new California law that increases punishment by five years for anyone using this information to commit a felony. CAL. Penal CODE $\$ 290.4$ (c)(1). Additionally, anyone using this information for a purpose other than protecting a child at risk will be liable for any damage as a result of this use, and may be subject to punitive damages as well. Id. $\$ 290.4(f)(3)$ (A). 
effective these provisions will be. In New Jersey, after local vigilantes broke into a sex offender's home and beat a man asleep on the couch, police arrested the attackers for assault. ${ }^{268}$ But when the harassment is subtle, yet pervasive, as when a sex offender is refused lodging, employment, and any type of regular societal interaction, ${ }^{269}$ the law may not be as quick to respond.

Based on the registration aspects of these models alone, both qualify as historical punishments. Furthermore, each has a deterrent effect based solely on its registration provision. The potential for public disclosure enhances this effect. ${ }^{270}$

Finally, these proposals are excessive in relation to their protective goal. Easy public access to an offender's criminal record hinders any meaningful participation in community life for the offender. Society's visceral response to information about sex offenders is more an expression of untempered fear than an attempt to meaningfully protect itself. Exposing the offender to public scrutiny is not the only way to protect the public. Legislatures may choose this method, but they must realize that it imposes further punishment on offenders.

\section{B. Cruel and Unusual Punishment}

The last section demonstrated that each model of community notification constitutes punishment. This raises the question of whether each model violates the Eighth Amendment's prohibition against cruel and unusual punishment. ${ }^{271}$ This section examines Supreme Court doctrine on the Eighth Amendment, and how lower courts have applied that doctrine to registration and community notification statutes. After having defined a workable Eighth Amendment standard, the section concludes with an analysis of each community notification model under that standard.

\section{Current Case Law}

The Supreme Court's Eighth Amendment doctrine currently lacks a solid foundation. For nearly a decade, from 1983 to 1991, the Court supported a proportionality test. In 1991, the Court divided over the test's validity, signalling that the Court may adopt a new standard in the near future. After examining the proportionality test, this section looks to the values underlying the Eighth Amendment in order to identify a new standard that could be applied im the community notification context.

268. Two N.J. Men Charged in Beating Sparked by Sex Offender Law, CH. TRrB., Jan. 11, 1995, Sec. 1 , at 3 .

269. See Daniel Golden, Sex-cons, Boston Globe MaG., Apr. 4, 1993, at 13, 13-14.

270. See supra note 217 and accompanying text.

271. See Solem v. Helm, 463 U.S. 277, 290 (1983) ("[N]o penalty is per se constitutional."), overruled in part by Harmelin v. Michigan, 501 U.S. 957 (1991). 


\section{a. The Proportionality Test}

i. Solem v. Helm

The Supreme Court has long interpreted the ban on "cruel and unusual punishment" to extend to "disproportionate" punishments. The Court enunciated a proportionality principle early in the twentieth century im Weems $v$. United States, where it noted that "it is a precept of justice that punishment for crime should be graduated and proportioned to offense."272 More recently, the Court has applied the proportionality principle frequently in capital sentencing cases. ${ }^{273}$

Solem $v$. Helm estabhished the validity of the proportionality principle for noncapital sentencing. ${ }^{274}$ The Court announced that any criminal sentence inay be subject to a proportionality analysis, as "no penalty is per se constitutional."275 The Court identified three elements to the proportionality test: (1) the gravity of the offense and the severity of the penalty; (2) punishment inposed on other crimes in the same jurisdiction; and (3) punishment imposed for the same crime in other jurisdictions. ${ }^{276}$

The first prong of the proportionality test requires courts to examine the severity of the penalty and the gravity of the crime. ${ }^{277}$ In determining the gravity of the crime, a court inay look at factors including "the harm caused or threatened to the victim or society," "the culpability of the offender," and "the offender's motive in committing the crime."278 With regard to the severity of the penalty, the Court has offered some illustrative examples, but no overarching guidelines. The Court has found that execution is undoubtedly a more severe punishment than imprisonment. ${ }^{279}$ The Court has also noted "a clear lime between sentences of inprisonment and sentences mvolving no deprivation of liberty."280 Lastly, there are obvious gradations in severity between different terms of imprisonment.

272. Weems v. United States, 217 U.S. 349, 367 (1910).

273. See, e.g., Enmund v. Florida, 458 U.S. 782, 797-98 (1982) (holding that the death penalty is disproportionate, and therefore unconstitutional, punishment for a felony murderer who does not kill, attempt to kill, or intend to kill); Coker v. Georgia, 433 U.S. 584, 592 (1977) (holding that the death penalty is disproportionate, and therefore constitutionally forbidden, punishment for the crime of rape).

274. 463 U.S. at $288-90$.

275. Id. at 290 . However, because Solem dealt specifieally with a sentence of imprisonment, the Court did not explicitly validate a proportionality analysis for a noncapital sentence that does not involve imprisonment, such as community notification punishments. Thus, it is impossible to know whether the Solem Court contemplated application of the proportionality test beyond the traditional punishments of imprisonment and death. Nonetheless, beeause the Court's language in Solem encompassed all criminal penalties, the proportionality test should apply in the community notification context.

276. Id. at 292.

277. Id.

278. Harmelin v. Michigan, 501 U.S. 957, 1022 (1991) (White, J., dissenting) (quoting Solem, 463 U.S. at 292-94).

279. Id. at 294.

280. Id. at 294 n. 18 . 
The second prong of the test compares the penalty at issue with penalties imposed for other offenses in the same jurisdiction. ${ }^{281}$ "If inore serious crimes are subject to the same penalty, or to less serious penalties, that is some indication that the punishment at issue may be excessive."282

Finally, the third element compares the penalty at issue with penalties imposed in other jurisdictions for the same crime. ${ }^{283}$ This prong suggests that the more "unique" a particular penalty is, the nnore likely it is that it violates the Cruel and Unusual Punishment Clause. However, courts applying this element in sex offender registration cases have routinely refused to allow uniqueness to impair the validity of a state statute. In State $v$. Lammie, for example, the court found that the existence of lifetime sex offender registration in only two other states was sufficient to satisfy this element. ${ }^{284}$ The court justified its holding by claiming that a stricter test would discourage states from being on the "leading edge" of criminal sentencing. ${ }^{285}$

Eight years later, in 1991, Harmelin v. Michigan ${ }^{286}$ questioned the validity of the Solem holding. In Harmelin, Justice Scalia, in an opinion joined by Chief Justice Rehnquist, argued that the Court should overrule Solem on the grounds that the proportionality principle was not supported by history or precedent and was an imvitation for judges to impose their own "subjective values."287 Three other justices found the proportionality principle unclear and inconsistent as announced in the Court's prior decisions, but voted to adhere to the principle on the grounds of stare decisis. ${ }^{288}$ Though Harmelin weakened the authority of Solem, the proportionality test remained intact, as seven justices voted to uphold the test. ${ }^{289}$

\section{ii. Application in Registration Case Law}

Since the Court's muddled decision in Harmelin, no court has fully considered an Eighth Amendment challenge to a registration or community notification law. Thus, nearly all of the decisions in this area have

281. Id. at 292.

282. Id. at 291.

283. Id. at 292 .

284. 793 P.2d 134, 140 (Ariz. Ct. App. 1990).

285. Id.

286. 501 U.S. 957 (1991).

287. Id. at 986 (Scalia, J., joined by Rehnquist, C.J.).

288. Id. at 996-97 (Kennedy, J., joined by O'Connor and Souter, JJ., concurring).

289. See id.; id. at 1021 (White, J., joined by Blackmun and Stevens, JJ., dissenting); id. at 1027-28 (Marshall, J., dissenting).

Solem indicated that no one factor in its test would be dispositive, but that a combination of objective factors should make up the analysis. Solem, 463 U.S. at 291 n.17. However, Justice Kennedy's concurring opinion in Harmelin suggested that only if the penalty proved "grossly disproportionate" to the offense under the first prong would it be necessary to turn to the second and third elements of the test. Harmelin, 501 U.S. at 1005 (Kennedy, J., concurring). 
employed the Solem test, or a similar proportionality test under a state constitution.

The lower court in People v. Adams relied on Solem to analyze Illinois' Habitual Child Sex Offender Registration Act. ${ }^{290}$ Under the first element of Solem, the court found that the very simple act of registration was not a severe penalty for criminals who have shown themselves to be serious dangers to society. ${ }^{291}$ Under the second element, the court found the registration requirement relatively lenient in comparison to the mandatory life sentences imposed on certam habitual crimmals in Illinois. ${ }^{292}$ Finally, the court compared the statute to other state laws regarding sex offenders. Although only seven other states required sex offender registration at that time, the court held that this number was sufficient to negate a claim that Illinois' statute was so umique as to render it cruel and unusual. ${ }^{293}$

In State v. Lammie, an Arizona appellate court considered a challenge to that state's registration law under the cruel and unusual pumishment clauses in botll the state and federal constitutions. ${ }^{294}$ The court first held that registration was not an unduly harsh pumishment for attempted sexual offenses, given the egregiousness of these offenses and the potential deterrent effect of registration on sex offenders. ${ }^{295}$ The court also noted that since the statute covered all sex-related crimes, Lammie's registration for an attempted sexual offense was not disproportionate to other punishments in Arizona. ${ }^{296}$ Finally, the Lammie court held that evidence of registration statutes in two other states satisfied the third Solem requirement. ${ }^{297}$

In State v. Douglas, an Ohio appellate court found that the state's habitual sex offender registration statute did not violate the Eighth Amendment. 298 The court in Douglas found that registration was a "modest burden" given its confidentiality and usefulness to the police. ${ }^{299}$ The court rejected the defendant's argument that the punishment was disproportionate because the state did not impose registration on other violent offenders such as robbers and murderers. On this issue, the court deferred to the presumed legislative judgment that registration of sex offenders would facilitate investigation of sex offenses. ${ }^{300}$ Finally, the court noted that, although few states imposed registration requirements on their convicted

290. 555 N.E.2d 761, 766-67 (IIl. App. Ct. 1990), aff'd, 581 N.E.2d 637 (Ill. 1991). The court's Eighth Amendment analysis was actually unnecessary, since the court first decided that the registration requirement was not punishment. Id. at 766.

291. Id. at 767.

292. Id.

293. Id.

294. 793 P.2d 134, 139-40 (Ariz. Ct. App. 1990).

295. Id.

296. Id. at 140.

297. Id.

298. 586 N.E.2d 1096, 1099 (Ohio Ct. App. 1989).

299. Id.

300. Id. 
sex offenders, "[t]he Eighth Amendment is not violated every time a state reaches a conclusion different from a majority of its sisters over how to best administer its criminal laws."301

In In re Reed, the California Supreme Court did not apply the Solem test, but used a standard applicable to the state constitution's cruel or unusual punishment clause that is almost identical to that in Solem. ${ }^{302}$ The Reed court found that petitioner's misdemeanor conviction for soliciting lewd or dissolute conduct constituted relatively minor misconduct and did not pose a threat to society, that several sexual and nonsexual crimes in California which posed a greater threat to society did not require registration, and that of the few states which imposed any sex offender registration requirements, California's was relatively severe. ${ }^{303}$ Therefore, the court found that registration, as applied to individuals convicted of soliciting lewd or dissolute conduct, was cruel or unusual punishment. ${ }^{304}$

\section{iii. Problems with the Proportionality Test}

The proportionality test has fallen out of favor with the Supreme Court, and hence may not be the best test for determining the constitutionality of cominunity notification laws. However, the Court has not offered any guidance to lower courts about what standard to apply. ${ }^{305}$ Assuming that the Solem test remains valid, because no subsequent decision has overruled it, we are still left with insufficient guidelines for analyzing community notification laws. Sex offender cominunity notification laws do not fit neatly into the Solem analysis, and the three elements yield inconsistent determinations rcgarding their constitutionality.

The factors offered by the Solem court to determine the "seriousness" of a crimie ${ }^{306}$ address whether a particular punishment is cruel and unusual as applied to the particular offender before the court. In contrast, the present analysis seeks to determine whether sex offender cominunity notification is cruel and unusual on its face. In other words, this analysis will

301. Id. (citing Spaziano v. Florida, 468 U.S. 447 (1984)).

302. In re Reed, 663 P.2d 216, 220-22 (Cal. 1983). First announced in In re Lynch, 503 P.2d 921 (Cal. 1972), the California proportionality test requires a court to consider three factors: (1) the nature of the offense and/or the offender, with regard to the danger they present to society; (2) a comparison of the penalty with other penalties for more serious crimes within the same jurisdiction; and (3) a comparison of the penalty with the penalties imposed in other jurisdictions for the same crime. Id. at 930-33.

Even though the Reed analysis was based on the state constitution, it is still relevant to our federal constitutional discussion. The California prohibition against crucl or unusual punishment, while phrased differently and stemming from a different source, is govemed by nearly identical judicial standards as the federal prohibition on cruel and unusual punishment.

303. Reed, 663 P.2d at 220-22.

304. Id. at 222.

305. See Artway v. Attorney General, 876 F. Supp. 666, 678 (D.N.J. 1995) ("[W] hat is clear from Harmelin is that clarity is now lacking as to the proper apphication of Eighth Amendment scrutiny to legislation such as [community notification laws].").

306. See supra text accompanying note 278 . 
consider whether community notification as a punishment for any sex offense is a violation of the Eighth Amendment. ${ }^{307}$

When considering sex offenses in the abstract rather than as committed by any particular offender, the only relevant factor is "the harm caused or threatened to the victim or society." No one would dispute that sex offenses are serious crimes. They can cause extreme physical and psychological harm to victims, which is significant in both its immediate and lasting effects. The harm to society is also severe, forcing people to live in fear of sex offenders.

The first prong of the Solem proportionality test also requires an analysis of the penalty's severity. While the Supreme Court has indicated that punishments which do not involve the deprivation of liberty are less severe than punishments which do, community notification does not fit intuitively into a particular place within the range of punishments. Community notification removes the offender from participation in community life. This isolation is not necessarily less severe than the physical isolation of imprisonment precisely because release into society carries with it the expectation that one will be able to live as part of society. The analysis is complicated by the fact that community notification is often a penalty imposed in addition to a term of imprisonment. ${ }^{308}$ The proportionality test gives little guidance on where to place this combination of penal sanctions im the spectrum of punishment.

The second prong of the proportionality test requires a comparison between community notification and the penalties imposed upon other crimes within each jurisdiction which enforces community notification. No other types of offenders are required to notify their communities after serving a prison sentence, ${ }^{309}$ so sex offenders have the unique burden of publicizing their crimes to the community.

Finally, the proportionality test calls for a comparison between community notification as a punishment for sex offenders and punishments for sex offenders in other jurisdictions. Given current trends, community notification is no longer an "unusual" punishment. Five states currently have community notification laws. ${ }^{310}$ Moreover, with the passage of the Violent Crime Control and Law Enforcement Act of 1994, which provides incen-

307. Whether community notification is an appropriate punishment for less severe offenses is a separate question beyond the scope of this Comment.

308. Thus, when the Adams appellate court stated that "any length of prison term is more serious a penalty than mere registration with local pohice authorities," People v. Adams, 555 N.E.2d 761, 767 (1ll. App. Ct. 1990), aff'd, 581 N.E.2d 637 (11l. 1991), it neglected to factor into its analysis the three-year prison term that was also part of Adams' sentence. See id. at 762.

309. Community notification bas been imposed as a condition of probation for other types of crimes, such as sboplifting and drunk driving, in several other jurisdictions, but no statute requires other offenders to notify their communities aftcr serving a prison sentence.

310. See Alaska Stat. § 12.63.010, -.020, -.100; Cal. Penal Code § 290; La. Rev. Stat. ANn. $\S \S 15: 540$ to :549; 1994 N.J. Sess. Law Serv. 128; WASH Rev. Code ANN. § 9A.44.130-.140. 
tives for states to enact community notification laws, many more states will likely enact such laws in the near future.

The application of the proportionality test to community notification laws thus yields inconclusive and conflicting answers as to their constitutionality. While the second prong points decisively toward the unconstitutionality of community notification laws, the third prong poimts as decisively toward their constitutionality. The first element fails to provide any concrete determination, because it lacks any guidelines on which to base an analysis of the punishment's severity. Although the Court has determined that harm to the victim and to society are factors which contribute to the severity of the crime, the Court has not issued similar guidelines for determining the severity of the penalty. Without a clear conception of the severity of the penalty in relation to the crime committed, it is impossible to complete the proportionality analysis as set out by the Court.

$A$ better test of cruel and unusual punishment would provide guidelimes or underlying values for determining the severity of the punishment. Without a clear standard, the proportionality test is ill equipped to analyze punishments which stray from traditional sanctions.

\section{b. The "Dignity of Man" Standard}

The "dignity of man" standard offers a solution to the proportionality test's failure to provide guidelines for measuring the disproportionality of a punishment. The Court first referred to the dignity of man in the Eighth Amendment context ${ }^{311}$ in Trop v. Dulles. ${ }^{312}$ The case involved a soldier convicted of desertion who was stripped of his United States citizenship as punishment. $^{313}$ The Court found this denationalization to be cruel and unusual punishment in violation of the Eighth Amendment. ${ }^{314}$ In considering the scope of the phrase "cruel and unusual," Justice Warren, writing for a majority of the Court, announced that "[t]he basic concept underlying the Eighth Amendment is nothing less than the dignity of man..3315 $\mathrm{He}$ explained that the power to punish inust "be exercised within the limits of civilized standards."316 It was a mark of "the progress of a maturing society" that these standards were not static, but evolving. ${ }^{317}$

Since Trop, the Court has repeatedly returned to the "dignity of man" analysis for guidance in deciding Eighth Amendment questions. Justice Stewart, in the plurality opinion im Gregg $v$. Georgia, explained that com-

311. The Court has referred to "human dignity" in constitutional analysis in a variety of other contexts. See generally Jordan J. Paust, Human Dignity as a Constitutional Right: A Jurisprudentially Based Inquiry Into Criteria and Content, 27 How. L.J. 145 (1984).

312. 356 U.S. 86,100 (1958).

313. Id. at $87-88$.

314. Id. at 101-04.

315. Id. at 100 .

316. Id.

317. Id. at 101 . 
porting with the dignity of man "means, at least, that the punishment [must] not be 'excessive." "318 Justice Stewart found that judging a punishment on its face, rather than as apphed, required consideration of two factors. First, the punishment cannot allow "the unnecessary and wanton infliction of pain." 119 Second, the penalty "must not be grossly out of proportion to the severity of the crime."320 If by this second eleinent, Stewart intended a proportionality analysis similar to the one in Solem, the "dignity of man" standard is of little use to the present analysis of community notification statutes, as explained above.

A more recent interpretation of the phrase takes a different approach. Referring to the mandate in Trop that the Eighth Amendment "inust draw its ineaning froin the evolving standards of decency that inark the progress of a maturing society,"321 the majority in $M c$ Cleskey $v$. Kemp said that the "dignity of man" standard is informed by "conteinporary values." 322 The measure of conteinporary values is objective and comes from two sources in particular: (1) decisions of state legislatures, and (2) sentencing decisions of juries. ${ }^{323}$ Because juries have no say over community notification, the analysis is reduced to tallying how many states have passed such laws. This interpretation of the clause is unsatisfying as well, because it neglccts the court's function as a check against the power of the legislature. ${ }^{324} \mathrm{~A}$ legislature's enactment of a particular law has never been a guarantee of its constitutionality.

In Furman v. Georgia, ${ }^{325}$ Justice Breunan wrote what is perhaps the most thorough discussion in a Supreine Court case of the "dignity of man" standard. ${ }^{326}$ Brennan wrote a concurring opinion in Furman to strike down the death penalty as cruel and unusual punishment. Referring to Trop, Brennan explamed that in order to comport with the dignity of man, "[ $[t]$ he State, even as it punishes, must treat its meinbers with respect for their mtrinsic worth as hunan beings." $" 327$ Punishments thus should avoid inflicting not only extreme physical pain ${ }^{328}$ but also "severe inental pain." Breunan noted that the punishment in Trop was struck down not for its physical effects, but rather for its psychological and inental effects. ${ }^{329}$

318. 428 U.S. 153,173 (1976).

319. Id.

320. Id.

321. Trop, 356 U.S. at 101.

322. 481 U.S. 279, 300 (1987) (quoting Gregg, 428 U.S. at 173).

323. Id. at 300 .

324. See Furman v. Georgia, 408 U.S. 238, 266-69 (1972) (Brennan, J., concurring) (discussing the role of the cruel and unusual punishment clause as "a constitutional check to ensure that when we come to punishments, no latitude ought to be left, nor dependence put on the virtue of representatives") (interual quotations omitted).

325. 408 U.S. 238 (1972).

326. See Paust, supra note 311 , at 165.

327. Furman, 408 U.S. at 270 (Brennan, J., concurring).

328. Id. at 271 .

329. Id. 
Considering the reasons why torture has been condemned in this country, Brennan reinarked:

$[W]$ e realize that the pain involved is not the only reason. The true significance of these punishments is that they treat members of the human race as nonhumans, as objects to be toyed with and discarded. They are thus inconsistent with the fundamental premise of the Clause that even the vilest criminal remains a human being possessed of common human dignity. ${ }^{330}$

A second principle guiding Brennan's Eighth Amendment analysis was that the state must not impose severe pumshment arbitrarily. ${ }^{331}$ This principle relates directly to the words of the Eighth Amendment, prohibiting the infliction of cruel and unusual punishment. Brennan derived this principle "from the notion that the State does not respect human dignity when, without reason, it inflicts upon some people a severe punishment that it does not inflict upon others. ${ }^{9332}$

Societal rejection of severe punishment is the third principle Brennan identifies in Furman. ${ }^{333}$ Searching for gnidelines to inake "the judicial determination [of societal acceptance or rejection] as objective as possible," Brennan concluded that actual use of a severe punishinent, rather than its availability, should be the measure of its acceptability in society. ${ }^{334}$ If jurors or judges rarely impose the severe penalties available to thein under law, the existence of such laws on the books does not accurately reflect their current acceptance in society.

Finally, Brennan announced that to accord with human dignity, a punishinent "must not be excessive."335 If a significantly less severe punishment is sufficient to achieve the state's purposes, the imposition of a more severe punishment "is unnecessary and therefore excessive." Brennan recognized that this last principle could call for a proportionality test, he rejected such an analysis, preferring instead to frame the issue as a determination of the least severe punishment necessary. ${ }^{337}$

Brennan's criteria represent the most comprehensive exposition of the meaning of the "dignity of man" in the Eighth Amendment context. Unfortunately, these four elements have not been explicitly invoked in subsequent opmions. In fact, there is no clear consensus on what the concept of the dignity of man means in the Eighth Amendinent context. The Court,

330. Id. at $272-73$.

331. Id, at 274.

332. Id.

333. Id, at 277 .

334. Id. at $277,279$.

335. Id. at 279 .

336. Id.

337. Id. at 280 ("Although the determination that a severe punishment is excessive may be grounded in a judgment that it is disproportionate to the crime, the more significant basis is that the punishment serves no penal purpose more effectively than a less severe punishment."). 
instead, has focused on the proportionality test and invoked the dignity of inan inerely for rhetorical flourish rather than as a inultifaceted guideline. Nonetheless, Brennan's analysis potentially offers clear standards for determining what punishment is cruel and unusual.

The following section applies Brennan's four-part test to the four coinmunity notification models. As the following analysis shows, Brennan's test highlights many of the probleins and excesses of community notification that were identified by the policy analysis in Part IV of this Comment. The Court may find Brennan's analysis useful as a replacennent for its ailing proportionality test, even though his analysis currently carries no weight in Eighth Amendment interpretation.

\section{Applying the "Dignity of Man" Standard to Community Notification Models}

Applying Brennan's principles to community notification demonstrates that the self-identification and police discretion models are cruel and unusual punishment. First, these punishments are "degradimg to the dignity of hunian beings." ${ }^{338}$ The offender is held up before the community as an object of scorn, hatred, and fear. He is forever labeled a sex offender, stripped of any other identity he might otherwise have in the eyes of society. To reduce a person to this label affronts his dignity by ignoring his identity as a hunian being and regarding him only as an object to be controlled and feared. The refusal to accord dignity to one human being reflects upon the dignity of the whole society. ${ }^{339}$

Though the third model-the police book model-does not generate the same publicity as the first two inodels, its effect on the identity of the sex offender is identical. A book of sex offenders is available at the police station, orgamized by community. The reader can peruse the entire book, looking at the "sex offenders." The identity of each sex offender is again reduced to this one label, whicl overshadows any other role he may play in the community.

Also, still within the first principle, is the infliction of severe inental and psychological pain. In rejecting the punishment of denationalization, Trop described its effects as follows:

It subjects the individual to a fate of ever-increasing fear and distress. He knows not what discriminations may be established against him ... . He nnay be subject to bamishment, a fate universally decried by civilized people. ... It is no answer to suggest that

338. Id. at 272.

339. See Paust, supra note 311 , at 152 (quoting Justice Wilson, "If the dignity of each singly is undiminished, the dignity of all jointly must be unimpaired," Chisholm v. Georgia, 2 U.S. (2 Dall.) 419, 456 (1793), and asserting that the converse is also likely true). 
all the disastrous consequences of this fate may not be brought to bear ... . The threat makes the punishment obnoxious. ${ }^{340}$

Such a description sounds remarkably like the effects of community notification laws on sex offenders. ${ }^{341}$

Not all community notification models will have this dehumanizing effect. Since the toll phone call model requires the mdividual to seek information about a particular individual, the offender is not reduced to his identity as a sex offender. He already has an identity in the mind of the caller before the request is made. This model appropriately restricts knowledge to situations in which it will be useful. The other three models operate without a specific context and therefore encourage the public to regard an individual solely as a sex offender.

Brennan's second principle bars the arbitrary imposition of severe punishments. Here, all four models of community notification are equally faulty. Community notification is a punishment reserved almost exclusively for sex offenders. ${ }^{342}$ Advocates of these laws cite sex offender recidivism as the reason for community notification. But, as Part II of this Comment demonstrated, the statistics touted by community notification advocates distort the facts about sex offender recidivism. If recidivism were truly the reason behind community notification laws, legislatures would impose them on burglars, robbers, and drug offenders, each of whom have higher overall recidivism rates than sex offenders. If the real reason were the severity of sex crimes, and the vulnerabihity of society to such crimes, murderers and other violent criminals would also be subject to cominunity notification. The reasons given for imposing cominunity notification on sex offenders simply do not justify imposing community notification solely on sex offenders.

The third principle addresses societal reaction to the pumishment, focusing on its actual use, not mere availability. Society does not appear to have rejected community notification. Congress recently passed a law whicl effectively orders the states to enact such statutes. ${ }^{343}$ Information concerning the actual use of community notification under the new federal law will not be available for several years, but it is clear that in the states that currently have cominunity notification, it is not a dead letter.

340. Trop v. Dulles, 356 U.S. 86, 102 (1958).

341. There is a crucial difference between the punishment in Trop and the punishment of community notification. In Trop, the Court was especially concerned with the potential for discrimination against the expatriate because, in effect, his statelessness lost him "the right to have rights." Id. In contrast, the sex offender loses none of his constitutional rights, as the Washington Supreme Court in Ward pointed out. State v. Ward, 869 P.2d 1062, 1073 (Wash. 1994).

342. The Violent Crime Control and Law Enforcement Act of 1994 also requires states to enact community notification laws for persons convicted of certain nonsexual offenses against children. Pub. L. No. 103-322, §170101(a)(3)(A)(i), (ii), 1994 U.S.C.C.A.N. (108 Stat.) 1796, 2039 (enumerating kidnapping and false imprisonment of a minor, except by a parent, as registrable offenses).

343. See supra note 123. 
Brennan's final principle holds that respect for human dignity requires that the pumishment must not be excessive-i.e., it cannot do more than necessary to achieve its penal purpose. Judged against their purported regulatory purpose, the self-identification, police discretion, and police book models are excessive. These models do more than is necessary to protect the public by distributing specific inforination about sex offenders to an unlimited audience. While some people can use this infornation to protect themselves, most people receive no such benefit. The information merely gives them a target for their fear. In contrast, the telephone request model is directed narrowly at providing imdividuals with limited information when a specific need arises. It therefore avoids an excessive scope.

Although commumity notification laws have no stated penal purpose, these laws tend to pander to vengeful impulses. ${ }^{344}$ Justice Murphy recognized the connection between human dignity and revenge when he referred to human dignity in a plea for ridding pumishment of "the ugly stignia of revenge and vindictiveness" because "despicable acts have a dangerous tendency to call forth primitive impulses of vengeance and retaliation among the victimized peoples."345 Although Justice Murphy was referring to atrocities committed during wartime, his words are equally applicable to sex offenses today.

Justice Brennan, when formulating his analysis in Furman, concluded that any pumishment must be judged agamst all four factors, and that the "convergence" of analysis under all four factors will determine whether a pumishment offends the dignity of man. ${ }^{346}$ Thus, a pumishment need not clearly offend each imdividual factor if the analysis as a whole indicates that the pumshment is cruel and unusual.

The first three models of commumity notification offend Brennan's first, second, and fourth criteria in that they impose severe mental pain in an arbitrary and excessive manner. The third factor-societal rejection of the pumishment-is mconclusive, given the recent genesis of commumity notifcation laws, but it appears that the laws have substantial public support. However, the combination of the other factors supports a finding that the first three models offend the dignity of man, and thus are unconstitutional under the Eighth Amendment.

The fourth model, however, should survive the "dignity of man" analysis. Though it fails the second element of the test, in that it relies on misperceptions about sex offenders for its existence and is thus to some extent an arbitrary iinposition of pumshment, its limited scope satisfies the first and fourth elements, regarding the severity of the pain inflicted and the excessiveness of the punishment. Like the first three models, the telephone request model appears to have public support, though its recent enactment

344. See supra notes 135-143 and accompanying text.

345. In re Yamashita, 327 U.S. 1, 29 (1946).

346. Furman v. Georgia, 408 U.S. 238, 282 (1972) (Brennan, J., concurring). 
bars any conclusive findings. In sum, the telephone request model may be a successful mechanism with which to protect the public from sex offenders without offending the Constitution.

The concern with the telephone request model is that, although the statute specifically limits dissemination of the information to particular mdividuals, ${ }^{347}$ the statute may be ineffective in restricting this information to a limited audience. The California statute warns that unauthorized users of this information are liable for any damages that they cause, and subject to potential civil penalties of up to $\$ 25,000 .^{348}$ Califorma law also imposes extra penalties on people who use telephone request information to commit crimes themselves. ${ }^{349}$ But the statute does not expressly prohibit people from passing on to their friends the information that they learn from the 900 number phone call. Word of mouth is a powerful weapon, and it could cause this fourth model to create the same problems with labeling and vengeance that are evident in the other commumity notification models.

\section{CONCLUSION}

Sex offender community notification laws have attracted widespread attention and support due to community dissatisfaction with the criminal justice process and legislative desperation to control sex offenders. However, most community notification proposals are problematic from a policy standpoint because they sacrifice an offender's humanity in the name of protecting the public. Moreover, most of these proposals are constitutionally infirm because they offend the dignity of man, and are thus cruel and unusual punishment.

Only one model-the telephone request model-may escape the probleins of the other community notification proposals. In theory it limits notification to those who are in immediate need of protection. However, the actual effects of this program reinam to be seen.

The other models of community notification fail to redress the problems they are meant to resolve. They provide no mechanism for tracking a sex offender as he relocates, and thus are as meffective as registration. In addition, community notification inflicts harm on the offender and the cominunity by imciting panic and violence, and needlessly shaming the offender before the entire comınunity. Legislatures should resist the temptation to junip on the community notification bandwagon, and courts should seriously consider imvalidating community notification laws as cruel and unusual punishment.

347. See Cal. Penal Code § 290.4(f)(1).

348. Id. $\S 290.4(\mathrm{f})(3)(\mathrm{A})$.

349. Id. § 290.4(c)(1)-(2). 
